\title{
Large-Scale Weather Regimes and Local Climate over the Western United States
}

\author{
ANDRew W. Robertson AND Michael GHIL \\ Department of Atmospheric Sciences and Institute of Geophysics and Planetary Physics, University of California, Los Angeles, \\ Los Angeles, California
}

(Manuscript received 21 January 1998, in final form 7 July 1998)

\begin{abstract}
Weather regimes are used to determine changes in the statistical distribution of winter precipitation and temperature at eight locations within the western United States. Six regimes are identified from daily 700-mb heights during 46 winters (1949-95) over the North Pacific sector applying cluster analysis; these include the Pacific-North American (PNA) pattern, reverse-PNA, a tropical-Northern Hemisphere (TNH) regime, and a Pacific $\Omega$ block. Most of the regimes have a statistically significant effect on the local median temperature, as well as daily temperature extremes; differences between locations are secondary to the large-scale effects. Local precipitation frequency is also conditioned significantly by certain weather regimes, but differences between groups of locations are larger. Precipitation extremes are dispersed and hard to classify. The dependence of local temperature statistics on the warm- or cold-air advection associated with particular weather regimes is discussed, as is the dependence of precipitation anomalies on the regimes' displaced storm tracks.

The extent to which the El Niño-Southern Oscillation modulates the probability of occurrence of each of the six weather regimes is then investigated. Warm event (El Niño) winters are found to be associated with a significant increase in prevalence of a TNH regime, in which negative height anomalies exhibit a northwestsoutheast tilt over the North Pacific. During La Niña winters, this TNH regime occurs significantly less frequently, while a regime characterized by a ridge over southwestern North America becomes more prevalent. These two regimes are associated with regional precipitation-frequency anomalies of opposite sign, that contribute to a north-south contrast in precipitation anomalies over the western United States during El Niño and La Niña winters. On interdecadal timescales, the frequency-of-occurrence of the PNA pattern is found to be notably higher during the 1970s and early 1980s.
\end{abstract}

\section{Introduction}

It is becoming increasingly well established that atmospheric intraseasonal variability is characterized by certain large-scale flow patterns that appear repeatedly at fixed geographical locations, and persist beyond the lifetime of individual synoptic-scale storms. These patterns were termed Grosswetterlagen by Bauer (1951), and have since been systematized in terms of teleconnection patterns (Wallace and Gutzler 1981) or persistent anomalies (Dole and Gordon 1983) in midtropospheric height fields. They are characterized by an approximately equivalent-barotropic vertical structure (Blackmon et al. 1979).

The concept of weather regimes (Rheinhold and Pierrehumbert 1982) or planetary flow regimes (Legras and Ghil 1985) has been introduced in attempting to connect the observations of persistent and recurring patterns with synoptic-scale or planetary-scale atmospheric

Corresponding author address: Dr. Andrew W. Robertson, Department of Atmospheric Sciences, UCLA, 405 Hilgard Ave., Los Angeles, CA 90095-1565.

E-mail: andy@atmos.ucla.edu dynamics. Regimes have been defined in terms of clustering, fuzzy (Mo and Ghil 1988) or hierarchical (Cheng and Wallace 1993), maxima in the probability density function (PDF) of the large-scale, low-frequency flow (Molteni et al. 1990; Kimoto and Ghil 1993a,b), or by quasi-stationarity (Ghil and Childress 1987, section 6d; Vautard 1990). Regimes typically persist for several days to two weeks, with rapid transitions between them associated with the nonlinearity of atmospheric dynamics; a Markov chain of transition probabilities describes well their predictability (Mo and Ghil 1988; Vautard et al. 1990; Kimoto and Ghil 1993b).

Weather regimes are known to organize midlatitude storms (e.g., Robertson and Metz 1990) and to be associated with significant temperature anomalies (Michelangeli et al. 1995). By inference, they affect local weather. On the other hand, there is evidence from observations and general circulation model (GCM) experiments that the distribution of weather regimes over the North Pacific in a given winter is affected by the El Niño-Southern Oscillation (ENSO; cf. Horel and Mechoso 1988; Molteni et al. 1993).

In addition to converging observational evidence, theoretical studies indicate that flow regimes can be as- 
sociated with important regularities of the large-scale atmosphere's attractor, either as multiple stable equilibria, representing the totality of the attractor (Charney and DeVore 1979; Benzi et al. 1986), or as unstable equilibria and limit cycles embedded in a strange attractor (Legras and Ghil 1985; Vautard and Legras 1988; Kimoto and Ghil 1993b). The sensitivity of weather regimes to small perturbations has important implications for medium-range weather forecasting (Miyakoda et al. 1983; Tibaldi and Molteni 1990; Corti and Palmer 1997). Using the Legras and Ghil (1985) model (Ghil and Childress 1987, section 6.5), the three-component Lorenz model (Molteni et al. 1993), or the observations (Kimoto 1989), it has been argued that external forcings on midlatitudes, associated with ENSO or anthropogenic effects, may affect systematically the PDF of weather regimes.

Hydrological models for surface water supply, hydroelectric power production, and agricultural production require as input local precipitation and temperature on a daily basis. Statistical models that relate these to large-scale weather types have been constructed by Bardossy and Plate (1992) based on a classification scheme traditionally used by the Deutscher Wetterdienst (German weather service). To identify the weather types most related to daily precipitation, investigators have used empirical orthogonal function (EOF) analyses of daily 700-mb geopotential heights (Dettinger and Cayan 1992) or sea level pressure together with 850 -mb temperature and geopotential heights (Wilson et al. 1992). Classification and regression tree analysis was used by Hughes et al. (1993) and Zorita et al. (1995). These latter studies seek optimal statistical "downscaling" relationships between the large-scale circulation and local daily conditions, without the benefit of any prior information on the phase-space structure of the large scales. Weather regimes provide a dynamical paradigm for characterizing the multimodal statistics of the planetaryscale climate system, and thus provide a natural point of departure for a downscaling method to local daily precipitation and temperature, that is, regional climate.

The aim of this paper is to investigate the extent to which objectively defined weather regimes determine the statistics of daily precipitation and temperature over the western United States in winter. This is the season in which weather regimes are most extensively documented, and the one in which the region receives the bulk of its water supply. We also investigate the extent to which ENSO affects the distribution of weather regimes itself. ENSO is known to affect precipitation and temperatures over the western United States in winter, and particularly the hydrologic extremes (Ropelewski and Halpert 1987, 1996; Cayan and Webb 1992), although the extent and systematic character of this influence have been a matter of debate (Namias and Cayan 1984; Mo et al. 1991; Dettinger et al. 1995; Gershunov and Barnett 1998).

The paper is organized as follows. Section 2 describes the datasets used, large-scale and local. In section 3, we construct conventional correlation maps to paint a broad-brush picture of the relationship between large and regional scales. Kimoto and Ghil (1993b) found that over the wintertime North Pacific, about $50 \%$ of days in a 37-yr observed dataset of 700-mb height maps fell into distinct flow regimes; these weather regimes are constructed in section 4 for our 46-winter (1949-95) dataset. In section 5, we stratify daily regional statistics by regime. Interannual and interdecadal relationships between Pacific sea surface temperatures (SSTs) and weather regime recurrence are examined in section 6 , with the conclusions summarized in section 7 .

\section{Datasets}

Two datasets are used, one for each of the two spatial scales of interest. For the large scale, we analyze the National Centers for Environmental Prediction (formerly known as the National Meteorological Center) twice-daily time series of 700-mb heights for 46 winters, December 1949-February 1995. The data are provided on a diamond grid (two shifted regular $10^{\circ}$ grids) over the Northern Hemisphere, from which we select the North Pacific-North American sector $\left(20^{\circ}-70^{\circ} \mathrm{N}\right.$, $\left.120^{\circ} \mathrm{E}-60^{\circ} \mathrm{W}\right)$. Some grid points north of $55^{\circ} \mathrm{N}$ are omitted, following Barnston and Livezey (1987), to obtain an approximately uniform-area grid of 184 points. To identify weather regimes, daily averages are formed for the $N=46 \times 90=4140$ days and the data are lowpass filtered with a half-power point at 10 days. The mean seasonal cycle is subtracted on a daily basis from the lowpass-filtered dataset. The number of independent degrees of freedom in the time series is estimated as $N / \tau$ $\approx 520$; here $\tau \approx 8$ days equals the decorrelation time of the leading principal component of the filtered and deseasonalized dataset; that is, the time lag at which the autocorrelation decreases to $1 / e$.

The regional dataset consists of daily precipitation totals together with daily temperature maxima and minima for eight small-extent regions within the western United States (kindly provided by D. Cayan and L. Riddle). Each regional time series consists of an average over four to six stations, constructed with the methodology described by Aguado et al. (1992). For the daily time series used here, 365 daily means and standard deviations were used in place of the 12 monthly values used by Aguado and coauthors (L. Riddle 1997, personal communication). Daily averages of temperature are formed from the daily maxima and minima.

The geographical locations of the stations that comprise each regional time series are given in Fig. 1 and Table 1. The eight time series span three broad geographical regions of the western United States: (a) Carson-Truckee and the Central Sierra in the Sierra Nevada of California; (b) western Washington and the Yellowstone River in the Pacific Northwest and northwestern interior, respectively; and (c) the Rio Grande 


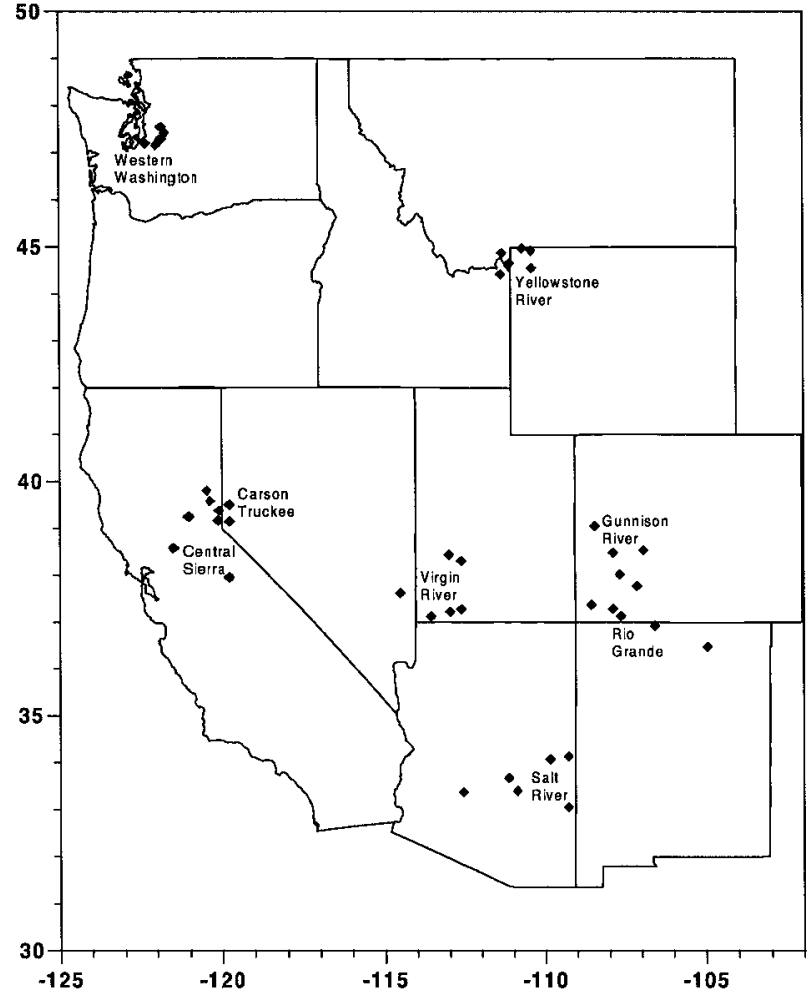

FIg. 1. Geographical location of stations that comprise the eight regional time series. The Carson-Truckee and Central Sierra time series have the Tahoe City station in common, while the Rio Grande and Gunnison River time series have the Gunnison and Durango stations in common.

and Gunnison, Salt, and Virgin Rivers in the southwestern interior (mostly within the Four Corners states). This daily dataset provides a measure of interregional variability across the western United States, while extending back to 1949 .

\section{Correlation maps}

To get an overall picture of the relationship between large and regional scales on interannual timescales, Figs. 2 and 3 show maps of the cross correlations between the interannual variability of winter [December-February (DJF)] means of 700-mb height on the one hand, and regional temperature and precipitation, respectively. Maps for three selected regions, from the Yellowstone River in the north to the Salt River in the south, are displayed in panels a-c of each figure.

Large-scale interannual fluctuations of geopotential height appear to accompany local variations of both precipitation and especially temperature, but the correlation patterns differ. Temperature exhibits very largescale negative cross correlations with $700-\mathrm{mb}$ heights over the entire North Pacific, for all three regions (Figs. $2 \mathrm{a}-\mathrm{c})$. The local cross correlations are positive, since 700-mb height reflects lower-tropospheric thickness- and thus surface-air temperature-when the vertical structure is equivalent barotropic. The largest correlations, however, are the negative ones upstream over the Pacific, and all three patterns broadly resemble the $\mathrm{Pa}$ cific-North American (PNA) teleconnection pattern (Wallace and Gutzler 1981). Excess winter precipitation is correlated locally with below-average geopotential heights, but the largest cross-correlation values for the Central Sierra and Salt River occur far away, off the West Coast (Figs. 3b,c). Sizable and coherent correlations occur upstream over the Pacific for the Yellowstone River as well (Fig. 3a), but the correlation patterns differ substantially from one region to another in the case of local precipitation.

\section{Weather regimes}

\section{a. Clustering methodology}

There is no unique or optimal way of classifying weather regimes, so we use two independent methods, based on pattern recurrence, to construct them: the PDF bump-hunting method of Fukunaga and Hostetler (1975), as used by Kimoto and Ghil (1993b; KG hereafter), and the $K$-means clustering method (MacQueen 1967), as used by Michelangeli et al. (1995; MVL hereafter). The PDF method defines a regime in terms of the state vectors of maps-or points in the large-scale atmosphere's state space-which lie in the vicinity of a PDF maximum, so that only a subset of the days is classified into regimes. The $K$-means method is a partitioning method that classifies all days into a predefined number of clusters; the method minimizes the sum of squared distances within the set of clusters (e.g., Anderson 1958). The PDF method describes the regimes in terms of localized subsets of the atmospheric attractor and thus provides a clear connection with the observational studies of recurrent large-scale patterns cited in the introduction, as well as with the results of the theoretical models discussed there. For these reasons, we will focus for the most part on the PDF regimes, while using the $K$-means method to test the robustness of our large-scale map classification and of its local weather implications.

Both methods were applied to the 46-winter dataset of 700-mb height maps for the North Pacific-North American sector prepared as described in section 2. The application was carried out as explained by $\mathrm{KG}$, in a subspace given by the leading EOFs. The latter are defined as the eigenvectors of the correlation matrix, which was found to yield slightly more regimes using the PDF bump-hunting method than does the covariance matrix (six vs four, see below). The bump-hunting method was coded independently, following the methodology of KG. An IMSL (1991) library program was used to implement the $K$-means method, with an initial $10 \%$ subset of points used to determine the initial seeds, and the clus- 
TABLE 1. Stations used in the eight regional time series.

\begin{tabular}{|c|c|c|c|}
\hline & Station & Location & $\begin{array}{c}\text { Elevation } \\
\text { (m) }\end{array}$ \\
\hline \multirow[t]{4}{*}{ Central Sierra } & Hetch Hetchy & $\left(38^{\circ} \mathrm{N}, 120^{\circ} \mathrm{W}\right)$ & 1180 \\
\hline & Nevada City & $\left(39^{\circ} \mathrm{N}, 121^{\circ} \mathrm{W}\right)$ & 847 \\
\hline & Sacramento & $\left(38.5^{\circ} \mathrm{N}, 121^{\circ} \mathrm{W}\right)$ & 24 \\
\hline & Tahoe City & $\left(39^{\circ} \mathrm{N}, 120^{\circ} \mathrm{W}\right)$ & 1899 \\
\hline \multirow[t]{6}{*}{ Carson-Truckee } & Boca & $\left(39.5^{\circ} \mathrm{N}, 120^{\circ} \mathrm{W}\right)$ & 1701 \\
\hline & Portola & $\left(40^{\circ} \mathrm{N}, 120.5^{\circ} \mathrm{W}\right)$ & 1478 \\
\hline & Sierraville & $\left(39.5^{\circ} \mathrm{N}, 120.5^{\circ} \mathrm{W}\right)$ & 1518 \\
\hline & Tahoe City & $\left(39^{\circ} \mathrm{N}, 120^{\circ} \mathrm{W}\right)$ & 1899 \\
\hline & Carson City & $\left(39^{\circ} \mathrm{N}, 120^{\circ} \mathrm{W}\right)$ & 1417 \\
\hline & Reno & $\left(39.5^{\circ} \mathrm{N}, 120^{\circ} \mathrm{W}\right)$ & 1341 \\
\hline \multirow[t]{6}{*}{ Gunnison River } & Cortez & $\left(37.5^{\circ} \mathrm{N}, 108.5^{\circ} \mathrm{W}\right)$ & 1893 \\
\hline & Durango & $\left(37.5^{\circ} \mathrm{N}, 108^{\circ} \mathrm{W}\right)$ & 2012 \\
\hline & Grand Junction & $\left(39^{\circ} \mathrm{N}, 108.5^{\circ} \mathrm{W}\right)$ & 1451 \\
\hline & Gunnison & $\left(38.5^{\circ} \mathrm{N}, 107^{\circ} \mathrm{W}\right)$ & 2335 \\
\hline & Montrose & $\left(38.5^{\circ} \mathrm{N}, 108^{\circ} \mathrm{W}\right)$ & 1777 \\
\hline & Ouray & $\left(38^{\circ} \mathrm{N}, 107.5^{\circ} \mathrm{W}\right)$ & 2390 \\
\hline \multirow[t]{6}{*}{ Rio Grande } & Chama & $\left(37^{\circ} \mathrm{N}, 106.5^{\circ} \mathrm{W}\right)$ & 2393 \\
\hline & Cimarron & $\left(36.5^{\circ} \mathrm{N}, 105^{\circ} \mathrm{W}\right)$ & 2393 \\
\hline & Durango & $\left(37.5^{\circ} \mathrm{N}, 108^{\circ} \mathrm{W}\right)$ & 2012 \\
\hline & Gunnison & $\left(38.5^{\circ} \mathrm{N}, 107^{\circ} \mathrm{W}\right)$ & 2335 \\
\hline & Hermit & $\left(38^{\circ} \mathrm{N}, 107^{\circ} \mathrm{W}\right)$ & 2743 \\
\hline & Ignacio & $\left(37^{\circ} \mathrm{N}, 107.5^{\circ} \mathrm{W}\right)$ & 1969 \\
\hline \multirow[t]{6}{*}{ Salt River } & Buckeye & $\left(33.5^{\circ} \mathrm{N}, 112.5^{\circ} \mathrm{W}\right)$ & 265 \\
\hline & Clifton & $\left(33^{\circ} \mathrm{N}, 109.5^{\circ} \mathrm{W}\right)$ & 1055 \\
\hline & Mc Nary & $\left(34^{\circ} \mathrm{N}, 110^{\circ} \mathrm{W}\right)$ & 2231 \\
\hline & Miami & $\left(33.5^{\circ} \mathrm{N}, 111^{\circ} \mathrm{W}\right)$ & 1085 \\
\hline & Roosevelt & $\left(34^{\circ} \mathrm{N}, 111^{\circ} \mathrm{W}\right)$ & 674 \\
\hline & Springerville & $\left(34^{\circ} \mathrm{N}, 109.5^{\circ} \mathrm{W}\right)$ & 2152 \\
\hline \multirow[t]{6}{*}{ Virgin River } & Beaver & $\left(38.5^{\circ} \mathrm{N}, 112.5^{\circ} \mathrm{W}\right)$ & 1811 \\
\hline & Caliente & $\left(37.5^{\circ} \mathrm{N}, 114.5^{\circ} \mathrm{W}\right)$ & 1341 \\
\hline & Milford & $\left(38.5^{\circ} \mathrm{N}, 113^{\circ} \mathrm{W}\right)$ & 1533 \\
\hline & Orderville & $\left(37.5^{\circ} \mathrm{N}, 112.5^{\circ} \mathrm{W}\right)$ & 1664 \\
\hline & St. George & $\left(37^{\circ} \mathrm{N}, 113.5^{\circ} \mathrm{W}\right)$ & 841 \\
\hline & Zion Natl. Park & $\left(37^{\circ} \mathrm{N}, 113^{\circ} \mathrm{W}\right)$ & 1234 \\
\hline \multirow[t]{5}{*}{ Western Washington } & Buckley & $\left(47^{\circ} \mathrm{N}, 112^{\circ} \mathrm{W}\right)$ & 210 \\
\hline & Cedar Lake & $\left(47.5^{\circ} \mathrm{N}, 112^{\circ} \mathrm{W}\right)$ & 475 \\
\hline & Palmer & $\left(47.5^{\circ} \mathrm{N}, 122^{\circ} \mathrm{W}\right)$ & 280 \\
\hline & Puyallup & $\left(47^{\circ} \mathrm{N}, 122.5^{\circ} \mathrm{W}\right)$ & 15 \\
\hline & Snoqualmie Fall & $\left(47.5^{\circ} \mathrm{N}, 122^{\circ} \mathrm{W}\right)$ & 134 \\
\hline \multirow[t]{6}{*}{ Yellowstone River } & Lake Yellowstone & $\left(44.5^{\circ} \mathrm{N}, 120^{\circ} \mathrm{W}\right)$ & 2368 \\
\hline & Tower Falls & $\left(45^{\circ} \mathrm{N}, 120^{\circ} \mathrm{W}\right)$ & 1911 \\
\hline & Yellowstone Natl. Park & $\left(45^{\circ} \mathrm{N}, 120^{\circ} \mathrm{W}\right)$ & 1890 \\
\hline & Island Park & $\left(44.5^{\circ} \mathrm{N}, 120^{\circ} \mathrm{W}\right)$ & 1917 \\
\hline & Hebgen Dam & $\left(45^{\circ} \mathrm{N}, 120^{\circ} \mathrm{W}\right)$ & 1978 \\
\hline & West Yellowstone & $\left(44.5^{\circ} \mathrm{N}, 120^{\circ} \mathrm{W}\right)$ & 2030 \\
\hline
\end{tabular}

tering repeated 50 times to eliminate any sensitivity to initial seeds (cf. MVL).

\section{b. Basic clustering results}

Bump hunting on the PDF in the subspace of the four leading EOFs - which account for $46 \%$ of the lowpassfiltered variability-yielded six regimes. Following Mo and Ghil (1988), we used an angular metric to define the clusters; the amplitude of daily height anomalies is thus not used as a criterion for weather-regime membership An Epanechnikov kernel was chosen in estimating the PDF from the daily dataset, filtered in time (low pass) and space (projection on the four leading
EOFs) as indicated above (cf. KG). In the angular metric, the cosine of the solid angle between points corresponds to the pattern correlation between the daily maps in physical space (Mo and Ghil 1988). Points within a radius of $r=30^{\circ}$ in solid angle of the peaks in the PDF were selected to define the clusters, which thus have a regular conical shape. This choice of $r$ gives negligible overlap between clusters and assigns $26 \%$ of the total 4140 days to one of them. All daily maps within a given cluster have a pattern correlation of $\cos \left(30^{\circ}\right)=$ 0.866 or greater with the central map, when considered within the spatiotemporally filtered dataset.

As in $\mathrm{KG}$, an automatic bump-hunting techniquevia the "mean-shift" algorithm of Fukunaga and Hos- 


\section{a) Yellowstone River}

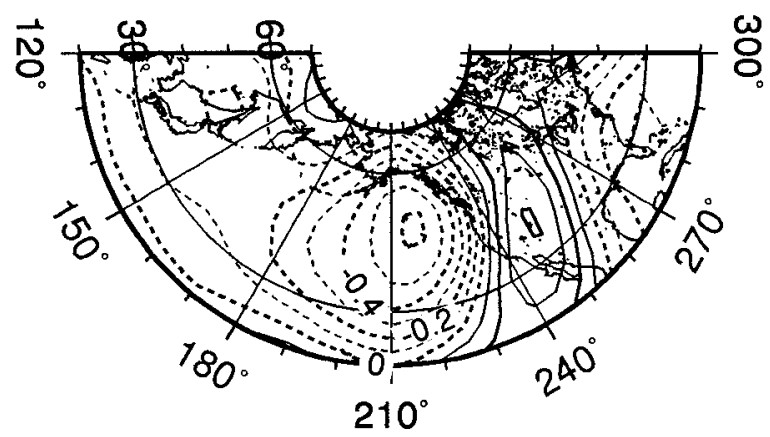

c) Salt River

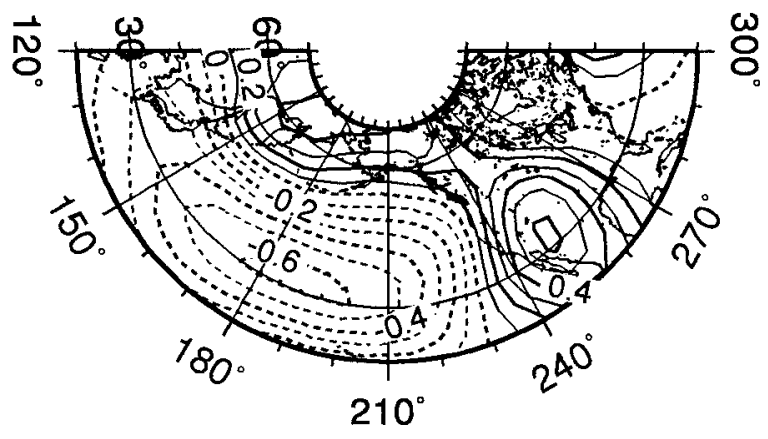

tetler (1975)_-was used to locate peaks in the PDF, starting from local maxima on the chronological trajectory. A chronological local maximum is defined in each successive 10-day segment of the time series if the daily map at the PDF maximum in that segment has a pattern correlation of less than 0.4 with the preceding local maximum so defined (KG). To determine the appropriate smoothing parameter $h$ for the Epanechnikov kernel, its value was varied between $30^{\circ}$ and $45^{\circ}$, and a range identified in which the number of clusters is insensitive to changes in $h$; results are shown for $h=40^{\circ}$, which lies within this range.

Figure 4 shows composite hemispheric maps of daily lowpass-filtered height anomalies for the six PDF regimes. With the exception of regime 1, all have close counterparts in the seven regimes identified by $\mathrm{KG}$ using the same methodology-see Table 2. Regimes 2 and 4 are the familiar PNA and reverse PNA (RNA), respectively, and closely resemble opposite phases of the onepoint correlation maps of Wallace and Gutzler (1981). The subtle asymmetry between regimes 2 and 4 was already identified by Dole (1986) in his study of persistent atmospheric anomalies over the Pacific. Regime 1 is broadly similar to the PNA, but its North American

\section{b) Central Sierra}

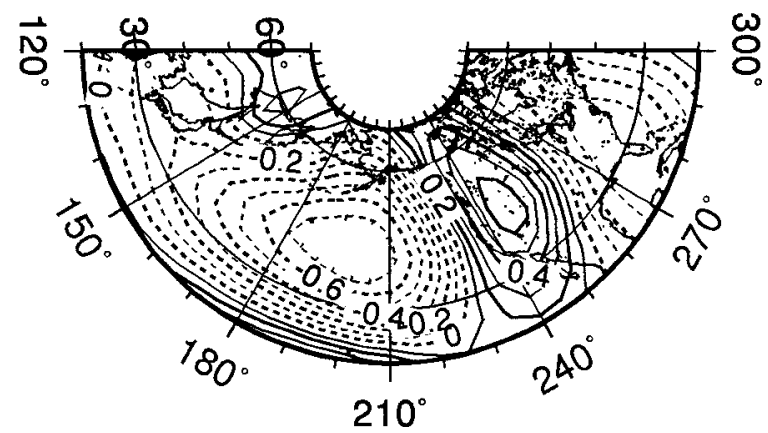

FIG. 2. Maps of the cross correlations between DJF means of local temperature and of DJF gridded 700-mb heights over the North Pacific-North American sector: (a) Yellowstone River, (b) Central Sierra, and (c) Salt River. Contour interval is 0.1, negative correlations dashed.

features are shifted eastward of those of the PNA, while the low center over the North Pacific has a northwestsoutheast tilt. It resembles the tropical-Northern Hemisphere (TNH) pattern identified by Barnston and Livezey (1985) and Mo (1985), particularly over North America. The western Pacific teleconnection pattern of Wallace and Gutzler (1981) does not appear, perhaps due to our particular choice of sector.

The three Pacific regimes identified by MVL are a subset of our six regimes (see Table 2). The comparison becomes very close if the covariance matrix is used to define the leading-EOF subspace, in which case only four clusters are obtained with $h=40^{\circ}$ (not shown). This smaller number of clusters is more consistent with MVL, who argue from a Monte Carlo test against red noise that only three clusters can be isolated from the observed record over the North Pacific [see also Smyth et al. (1999) for a detailed discussion of this point]. For the purposes of this study, however, we chose to work in the subspace of the correlation EOFs that yield 6 rather than 4 regimes. The larger set of regimes increases the opportunities for uncovering local-weather dependencies on large-scale weather regime; a smaller set may tend to smear these out. 


\section{a) Yellowstone River}

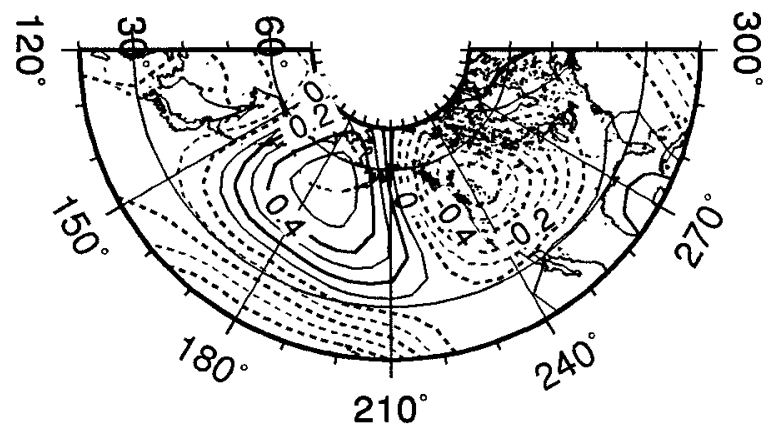

\section{c) Salt River}

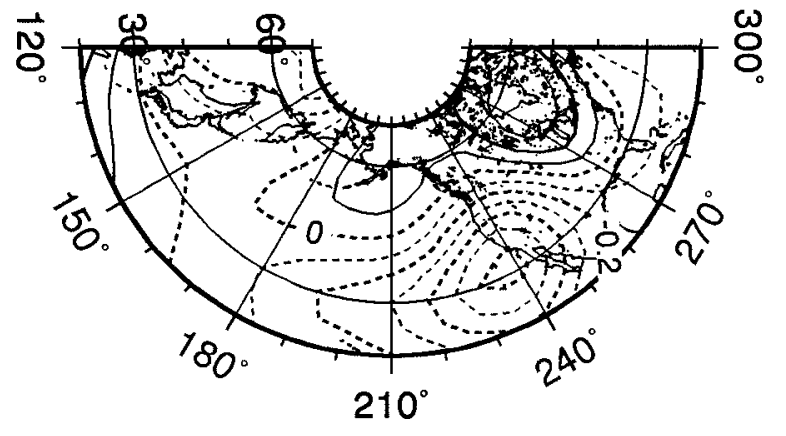

\section{c. Robustness of the results}

Repeating the $K$-means analysis for $K=4$ in the subspace of the 10 leading covariance EOFs, and $K=$ 6 using the 10 leading correlation EOFs, yields regime composite maps (not shown) in close correspondence with the PDF regimes in both cases. For $K=6$, the pattern correlations of each PDF regime in Fig. 4 with its $K$-means counterpart are $0.94,0.92,0.63,0.85,0.95$, and 0.98 , respectively. The agreement in pattern is very close in most cases, despite the fact that the $K$-means method was intentionally applied in an EOF subspace of higher dimension and using a Euclidean metric rather than the angular one used in the PDF method; the higherorder EOFs - which account for an additional $30 \%$ of the lowpass-filtered variance-evidently contribute but little to the cluster structure. The level of agreement is quite remarkable, given that the six PDF regimes account for only $26 \%$ of days, while all days are classified by the $K$-means method.

Larger clusters can be obtained using the PDF bumphunting method by increasing their radius $r$, but only at the expense of overlapping clusters. Hannachi and Legras (1995) have circumvented this problem by relaxing the requirement that the clusters have regular conical b) Central Sierra

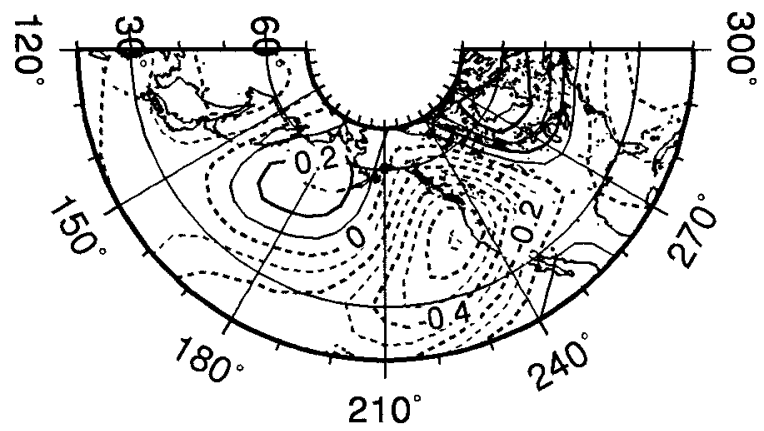

FIG. 3. As in Fig. 2 but for local DJF precipitation in the three regions.

shape. They used a simulated annealing method to allow irregular boundaries, based on solving a traveling salesman problem (TSP; Press et al. 1992). The TSP finds, iteratively, the shortest closed path between "cities," which in this case are the points in the EOF state space defined by the daily 700-mb height maps. We have applied the TSP to assign nonclassified days to their nearest cluster, using the clusters in Fig. 4 as our point of departure. All remaining days can be classified in this way, but we choose to assign only daily maps within an angular distance of $60^{\circ}$ (i.e., a pattern correlation of $0.5)$ of the cluster centroids. The resulting regime composites have pattern correlations of 0.986 or greater with those in Fig. 4, and contain 491, 361, 361, 300, 275, and 309 days, respectively, making up a total of 2097 or $51 \%$ of the 4140 daily maps.

\section{Regional statistics \\ a. Temperature statistics}

The weather regime patterns in Fig. 4 are sign-definite but are broadly consistent with the linear correlation maps in Figs. 2 and 3. From a regime perspective, warmer winters in the central Sierra Nevada, for example, 
a) Regime 1

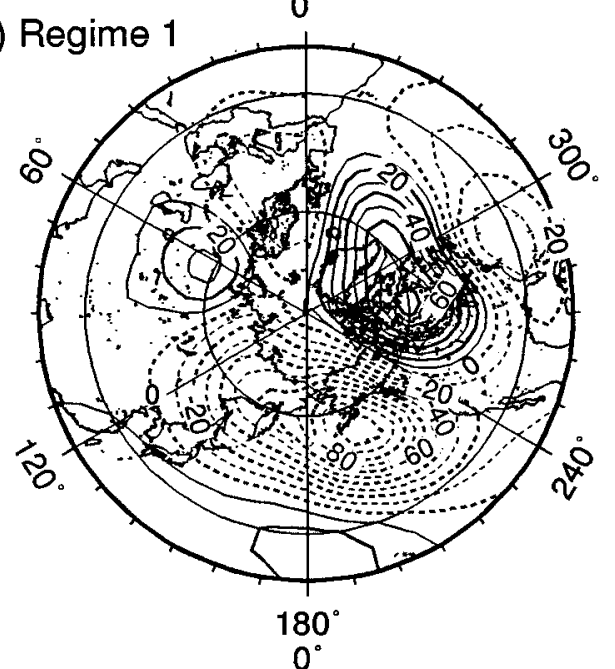

c) Regime 3

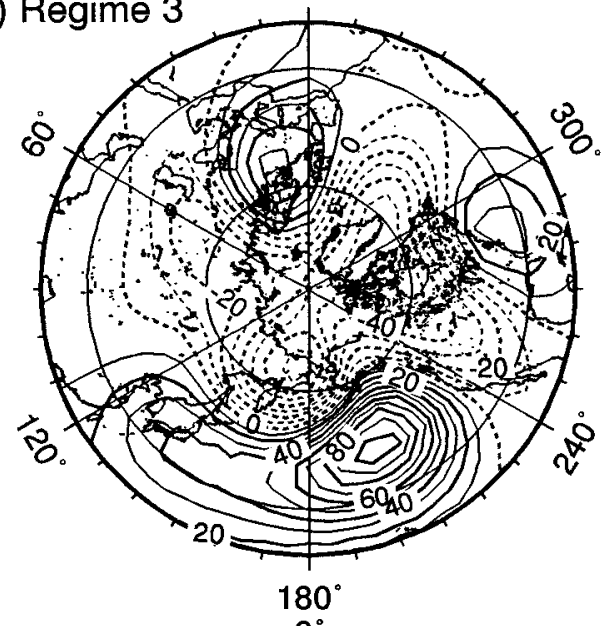

e) Regime 5

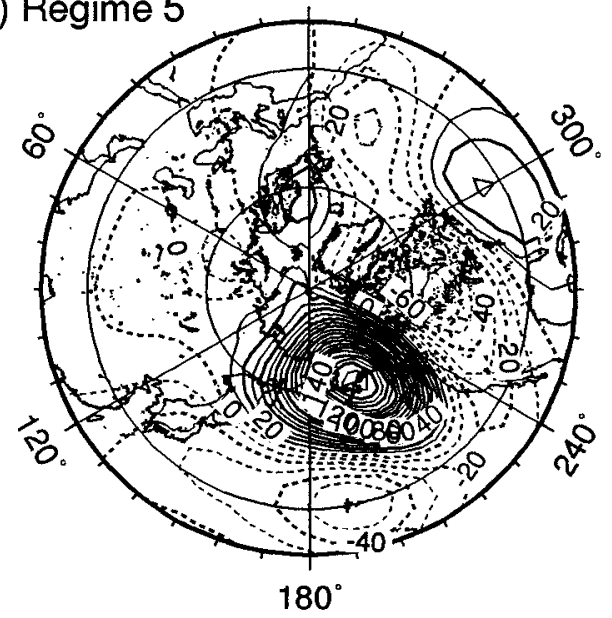

b) Regime 2

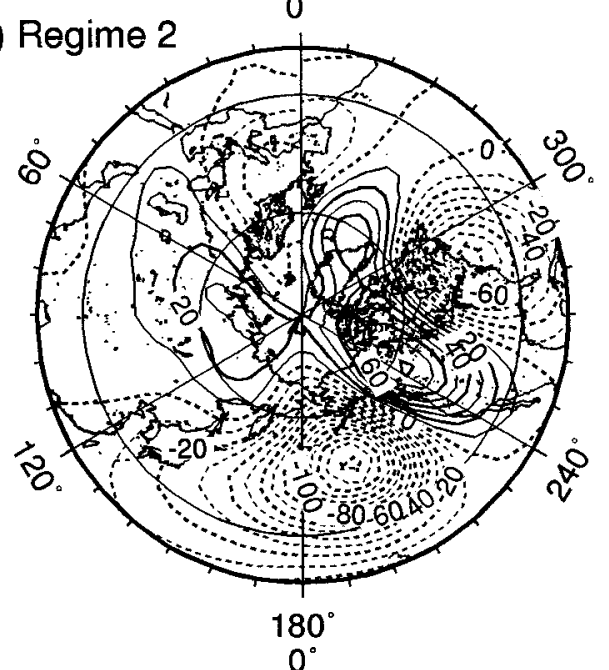

d) Regime 4

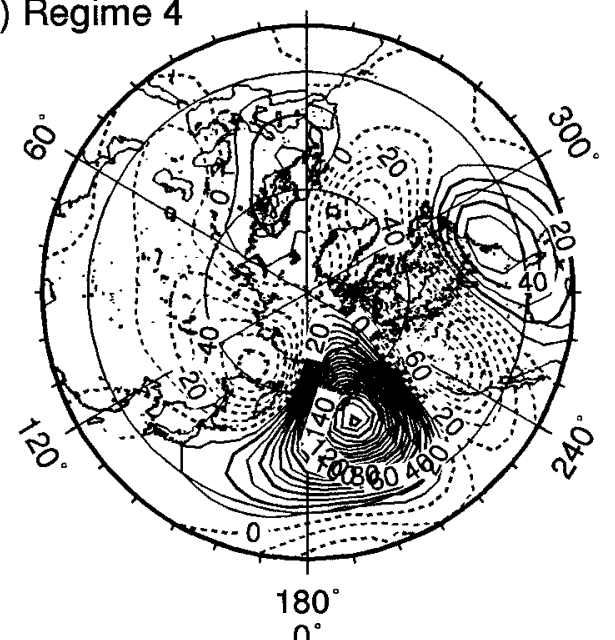

f) Regime 6

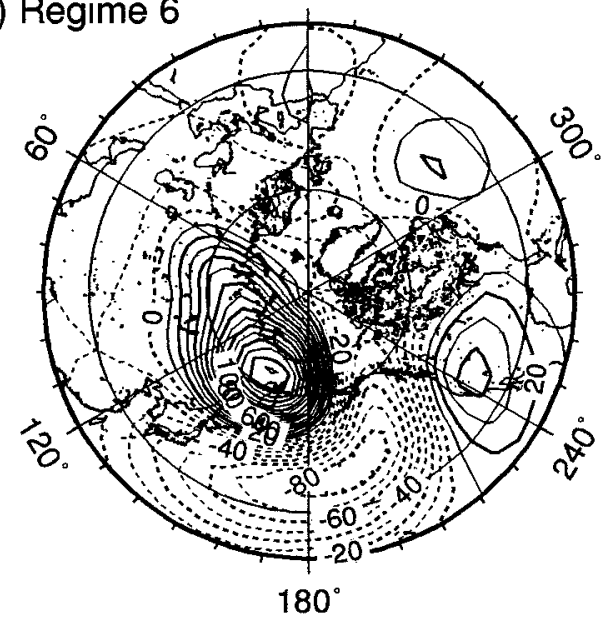

FIg. 4. North Pacific-North American weather regimes, constructed using the PDF bump-hunting method. Each map is the arithmetic average of hemispheric lowpass-filtered (and deseasonalized) 700-mb height anomalies on days belonging to that regime, not restricted to the leading EOFs; units are geopotential meters ( $\mathrm{gpm}$ ) and the contour interval is $10 \mathrm{gpm}$. The regimes are ranked according to their respective local PDF maximum, and contain 235, 206, 185, 181, 151, and 156 days, respectively. 
TABle 2. A comparison of the PDF regimes with weather regimes. Here KG is Kimoto and Ghil (1993b) and MVL is Michelangeli et al. (1995). Column 3 gives the pattern correlations between regimes identified using PDF bump-hunting and $K$-means methods. The association of regimes 1 and 6 with warm and cold events in the tropical Pacific is described in section 6.

\begin{tabular}{|c|c|c|c|c|}
\hline \multirow{2}{*}{$\begin{array}{l}\text { Regime } \\
\text { no. }\end{array}$} & \multirow[b]{2}{*}{ Description } & \multirow{2}{*}{$\begin{array}{l}\text { Correlation between } \\
\text { PDF and } K \text {-means } \\
\text { regimes }\end{array}$} & \multicolumn{2}{|c|}{$\begin{array}{l}\text { Corresponding regime } \\
\text { found in other studies }\end{array}$} \\
\hline & & & KG & MVL \\
\hline 1 & “El Niño"/TNH & 0.94 & - & - \\
\hline 2 & PNA & 0.92 & 1 & 2 \\
\hline 3 & & 0.63 & $3 \& 4$ & 1 \\
\hline 4 & Reverse PNA & 0.85 & 2 & 3 \\
\hline 5 & $\Omega$ block & 0.95 & 6 & - \\
\hline 6 & "La Niña" & 0.98 & 5 & - \\
\hline
\end{tabular}

appear from Fig. 2 to be characterized by above-normal prevalence of a PNA-like pattern. We now quantify the relationship between the weather regimes and local precipitation and temperature in each region.

In this section and the next, we use the six regimes derived using the PDF bump-hunting method with conical clusters (Fig. 4), unless stated otherwise. All the computations have been repeated using the larger clusters obtained with both simulated annealing (51\% of maps classified) and the $K$-means method (100\% classified). In each case, the results and their statistical significance are qualitatively very similar to those shown. The magnitudes of the regional anomalies are generally smaller in the latter two cases because the clusters are larger (not shown).

The distribution of daily temperature is approximately Gaussian (Dettinger and Cayan 1992). For each weather regime in turn, we compare the median and the two tails of the distribution of daily temperature with those de- fined by the full 46-winter record. The relative frequency of days warmer than the local winter median temperature for each weather regime is plotted in Fig. 5 . For example, a frequency change of $+40 \%$ means that days warmer than the climatological median occur $40 \%$ more often in the subset of days belonging to that regime, than the expected $50 \%$. The error bars show the 95\% confidence limits, derived using a simple reshuffling Monte Carlo procedure with 1000 random shuffles. Note that these error bars neglect persistence within regimes, and so will tend to be somewhat tighter than a more detailed statistical model might yield. Deviations in the frequency of warmer-than-median days are generally statistically significant at all localities for most regimes.

The principal regime dependence of the number of warm days is between regimes characterized by ridging over the North Pacific and a trough over the western United States (regimes 3, 4, 5), on the one hand, and
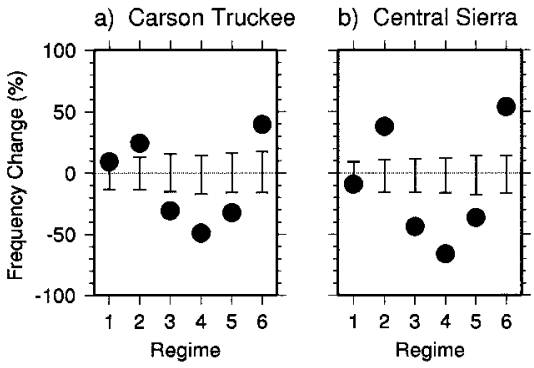

e) Salt River

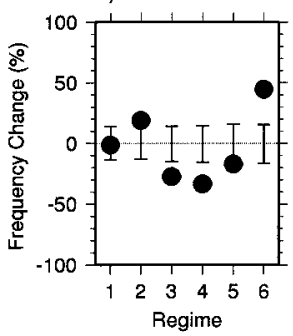

f) Virgin River

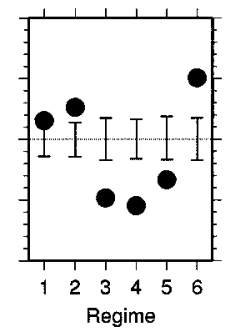

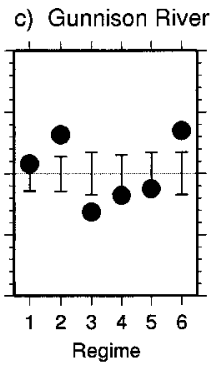

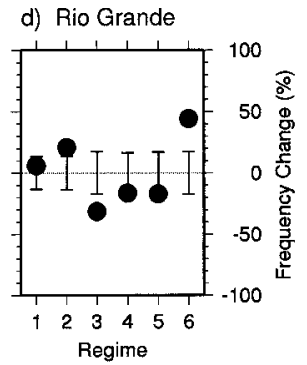

g) W. Washington

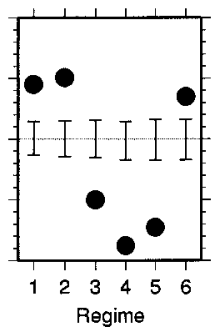

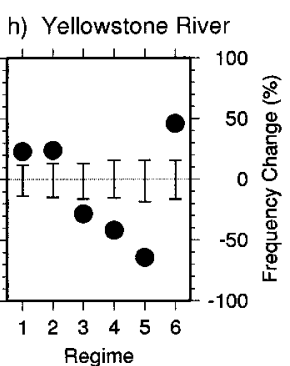

FIG. 5. Frequency of days belonging to each regime for which local daily average temperatures are above the climatological median, expressed as deviations (\%) from the expected 50\%. Error bars denote the $95 \%$ confidence interval, based on randomly reshuffling the 4140 days 1000 times. 
regimes with zonal anomalies over the Pacific with a downstream ridge (regimes 1, 2, 6), on the other. The latter contain more warmer days than average, and the former less. Regimes 2 and 4 constitute opposite phases of the PNA, and the large temperature difference at most stations between them is consistent with the correlation patterns in Fig. 2. The largest regime deviations in median temperature are in the Sierra Nevada and the Pacific Northwest.

To aid physical interpretation of the link between weather regimes and temperatures over the western United States, we show in Fig. 6 composites of the total unfiltered 700-mb height for each regime, together with the positions of the storm tracks plotted as the variance maxima in the 2.5-6-day bandpass (Blackmon and Lau 1980). The PNA (regime 2) exhibits a strong ridge over the western United States, with warm-air advection into the continent, while the RNA (regime 4) shows a trough that is accompanied by cold-air advection onshore. The other regimes show these opposing features to varying degrees.

Deviations in the frequency of temperature extremes, defined by the $10 \%$ tails of the daily maximum or minimum temperature distributions, are plotted in Fig. 7. The differences in daily temperature extremes are generally much larger than those in central tendency (note different scales on the ordinate). Both are generally in the same sense as for the median, with some exceptions. Changes in the cold tail tend to be larger than those in the warm tail in the Sierra Nevada. Despite the much smaller sample sizes, most of the deviations in the tails of the temperature distribution are also statistically significant. Regional differences are more marked in the distribution tails: regime 5 ( $\Omega$ block) is associated with more extremely cold days in western Washington, the Yellowstone River region, and the Southwest, while regime 4 (the RNA) is most often associated with extreme cold in the Sierra Nevada. This regional temperature difference can be interpreted in terms of slight differences in the position of the trough axis over North America (Figs. 6d and 6e).

\section{b. Precipitation statistics}

Daily precipitation has a one-tailed distribution that is well approximated by the gamma distribution (Dettinger and Cayan 1992). We focus first on the number of days with recorded precipitation, and then consider the tail of the distribution. Differences in the frequency of wet days between each regime and climatology are displayed in Fig. 8. The regime-dependence of precipitation frequency is slightly less clear-cut than for temperature, with fewer results that are statistically significant. However, the PNA regime (regime 2) is significantly drier at almost all localities, while its "reverse," the RNA (regime 4) is significantly wetter; the exceptions-Salt River for PNA and western Washington for RNA-have precipitation anomalies of the same sign as the other locations, only less significant. The other "Pacific ridge" regimes (regimes 3 and 5) tend to be wetter in the Southwest as well. These precipitation differences can be interpreted in terms of shifts in the storm tracks. The PNA storm track over the eastern Pacific is deflected to the north into Alaska (Fig. 6b), while the RNA storm track is steered southeastward from the far north Pacific into the western United States (Fig. 6d).

Regimes 1 and 6 (associated preferentially with El Niño and La Niña, respectively, see below) also show frequency anomalies of different signs by region. Regime 6 is significantly drier in the south but wetter in the north, due to a northeastward storm-track extension (Fig. 6f). Regime 1 is significantly wetter in the Sierra Nevada and parts of the Southwest, but drier at the Yellowstone River. These features are associated with an almost zonal eastward extension of the storm track (Fig. 6a); the latter is known to be characteristic of El Niño winters. Very similar results are obtained if the frequency of days with greater than $2.5 \mathrm{~mm}$ of precipitation is considered (not shown).

Heavy precipitation events are defined here as having daily totals that exceed the 75 th percentile of days with measurable precipitation. Changes in the frequency are generally not statistically significant. Only about one to two regimes per location lead to heavy-precipitation days that are significantly more or less frequent than for the entire dataset, at the $95 \%$ level or nearly so (not shown). In contrast to temperature extremes, regime deviations in heavy-precipitation frequency are in general no larger than those of precipitation frequency itself. Only in western Washington do three out of the six regimes show significant deviations in heavy precipitation. Here, regime 6 is associated with more frequent heavy precipitation events. In the Southwest, by contrast, regime 5 tends to be associated with heavy precipitation (not shown).

\section{c. Sensitivity tests}

Since only about a quarter of days are classified into regimes by the PDF bump-hunting method, year-to-year changes in local temperature or precipitation anomalies are not necessarily accounted for fully by changes in weather regime frequency. To check the extent to which the local winter anomalies are determined by regime frequency changes, regime frequencies were computed for anomalous winters in each of the eight regions, defined as local winter-averaged anomalies-in temperature or precipitation frequency-of greater than one standard deviation. Again a simple Monte Carlo scheme was used to estimate statistical significance, in which the winters were reshuffled 1000 times prior to calculating the statistics. Figure 9 illustrates the differences in frequency between warm and cold winters (circles), and wet and dry winters (diamonds), using the $K$-means regimes. The error bars indicate the $90 \%$ confidence interval. Similar results were obtained using the PDF 
a)

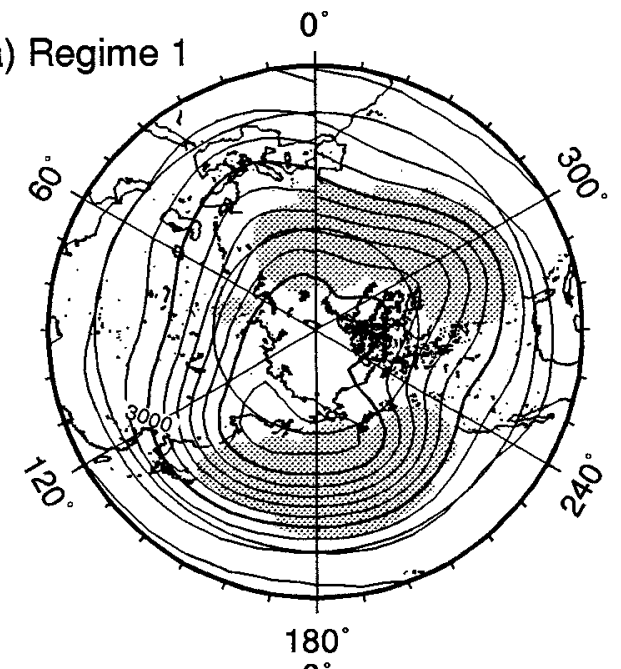

c) Regime 3

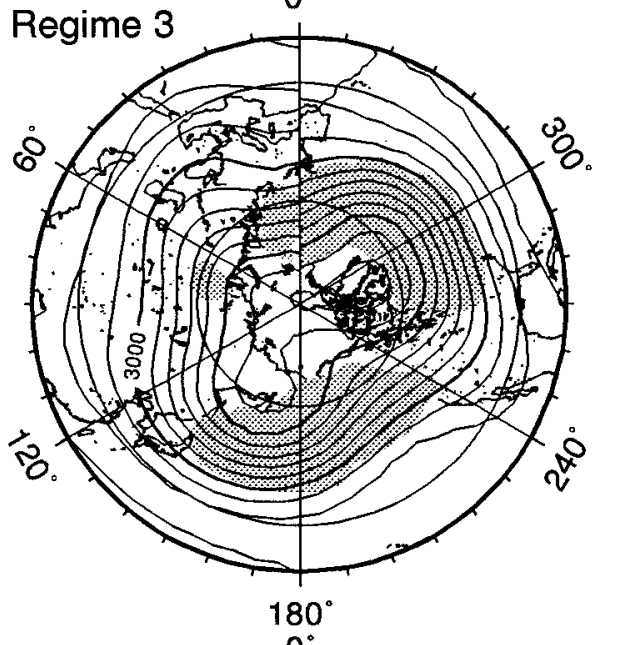

e) Regime 5

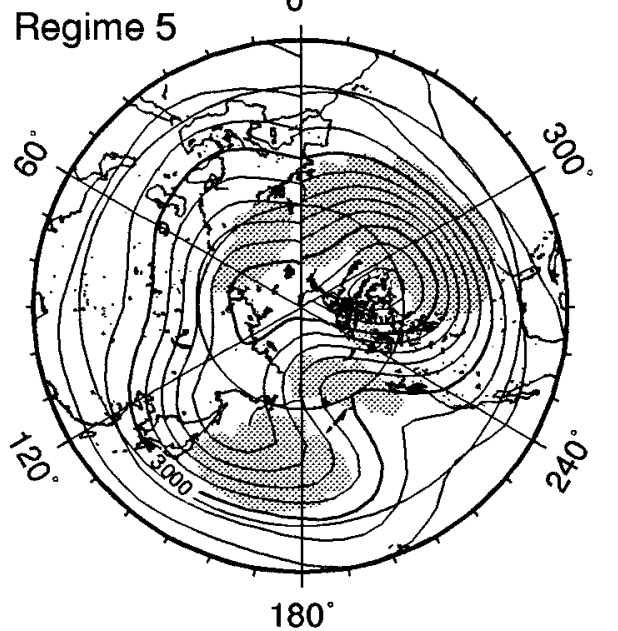

b) Regime 2

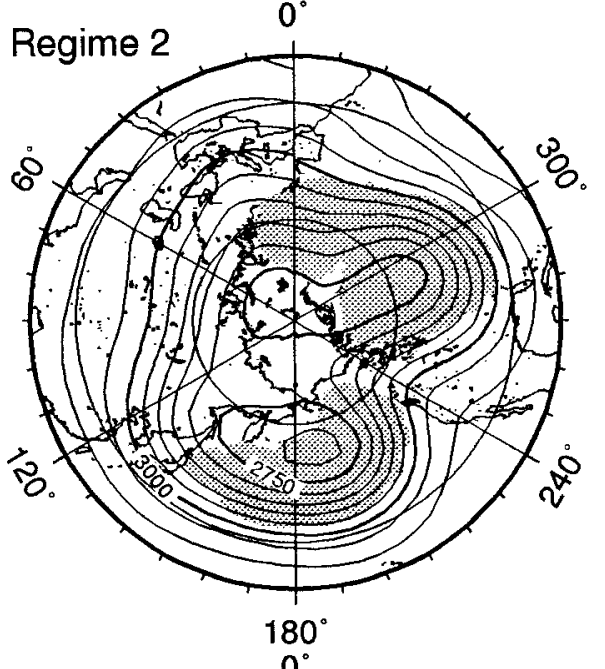

d) Regime 4

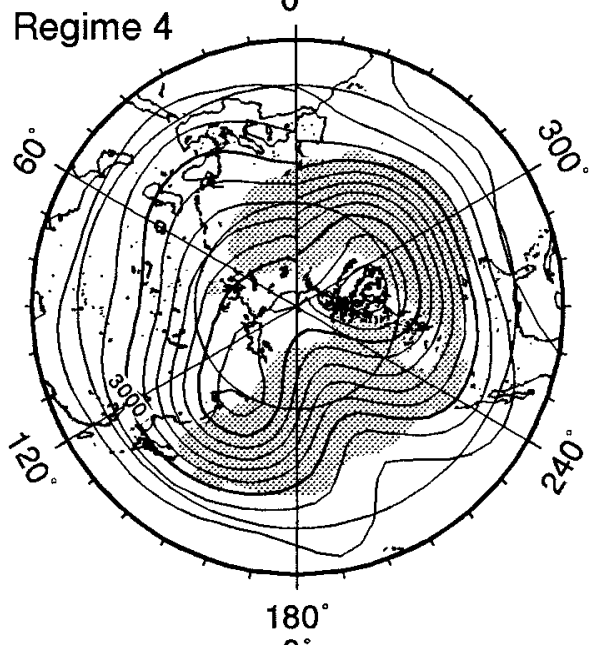

f) Regime 6

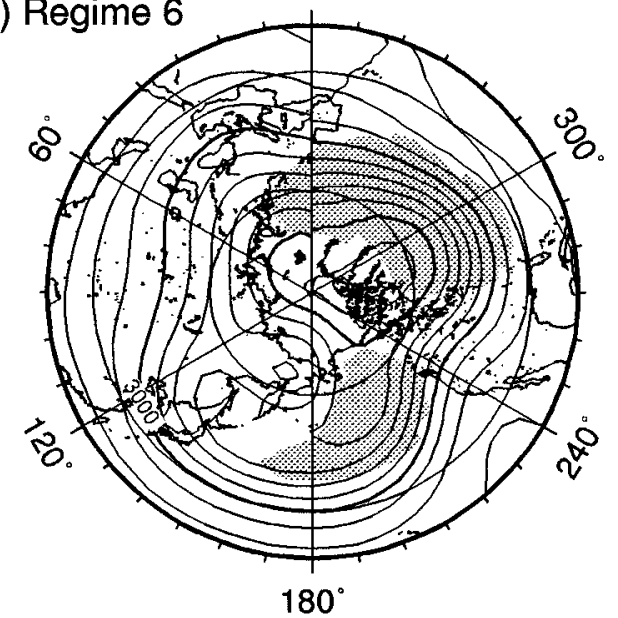

FIG. 6. Weather regime composites of unfiltered $700-\mathrm{mb}$ total height fields (contour interval $50 \mathrm{gpm}$ ) and regions where bandpass (2.5-6 days) variance calculated for the days spent in the corresponding regime exceeds $800 \mathrm{~m}^{2}$ (stippled). Details as in Fig. 4. 
a) Carson Truckee

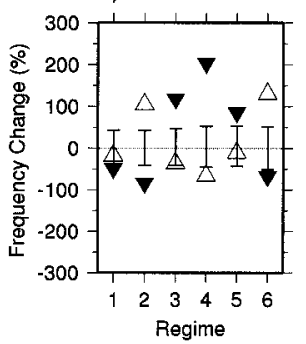

e) Salt River

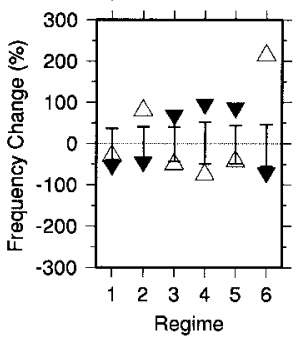

b) Central Sierra

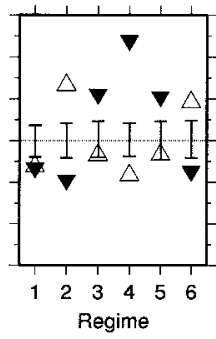

f) Virgin River

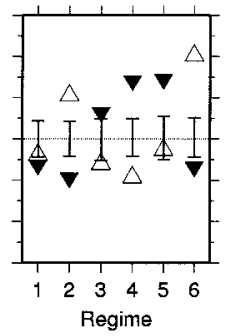

c) Gunnison River

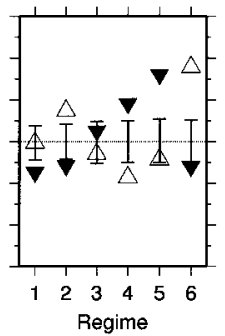

g) W. WashTigton

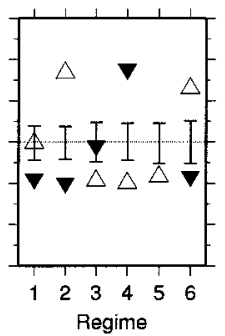

d) Rio Grande

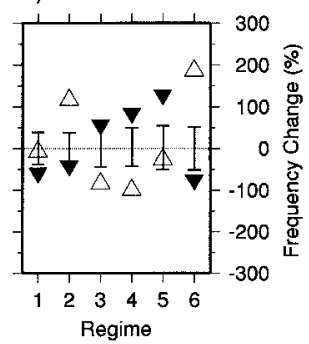

h) Yellowstone River

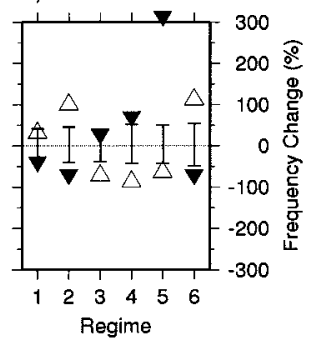

FIG. 7. Frequency of extreme warm and extreme cold days: (i) days belonging to each regime for which local daily maximum temperatures are above the climatological 90th percentile $(\triangle)$, and (ii) days for which daily minimum temperatures are below the 10th percentile ( $\nabla$ ); both expressed as deviations (\%) from the expected $10 \%$. Error bars denote the $95 \%$ confidence interval, based on randomly reshuffling the 4140 daily maximum temperatures 1000 times.

method, but the levels of significance were generally below the $90 \%$ level.

Overall, the correspondence is good between regimes that are significantly associated with anomalous local weather on a daily basis (Figs. 5 and 8 ) and those whose frequency of occurrence changes during anomalous win- ters (Fig. 9). The statistical significance of the latter is somewhat lower-for reasons associated with lower sample size-and the main feature is the contrast between winters dominated by the PNA (regime 2) compared to the RNA (regime 4). At most stations throughout the western United States, winters with a high re- a) Carson Truckee

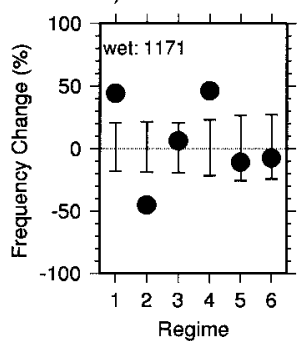

e) Salt River

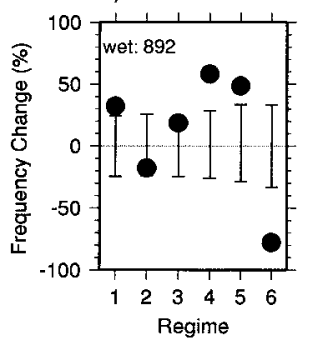

b) Central Sierra

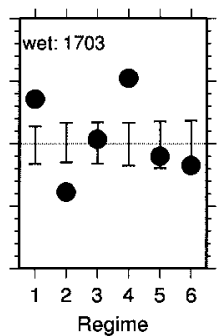

f) Virgin River

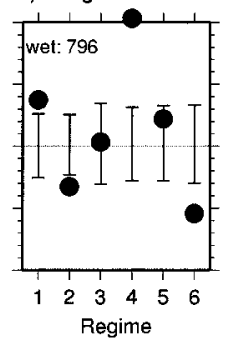

c) Gunnison River

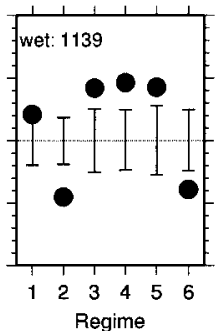

g) W. Washington

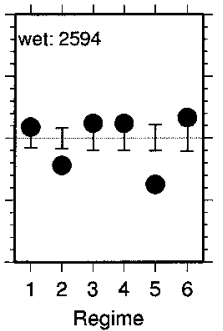

d) Rio Grande

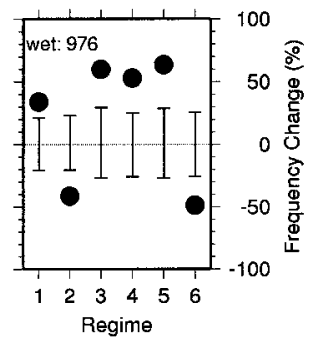

h) Yellowstone River

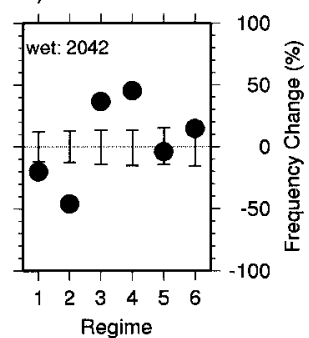

FIG. 8. Frequency of days belonging to each regime on which precipitation was recorded, expressed as deviations (\%) from the 46-winter climatological frequency. The total number of days with recorded precipitation is given in the top left-hand corner. Details as in Fig. 5. 
a) Carson Truckee

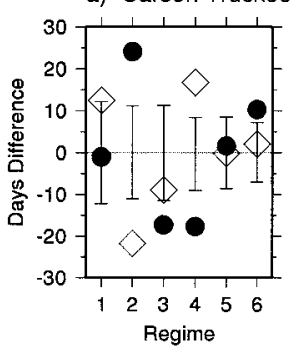

e) Salt River

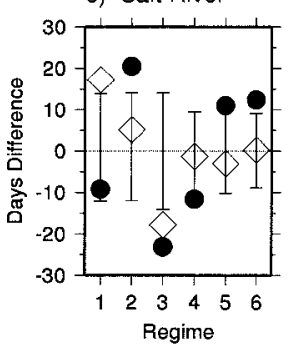

b) Central Sierra

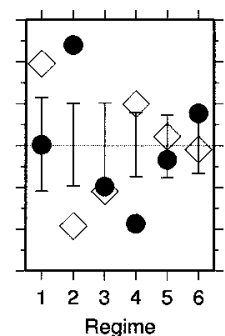

f) Virgin River

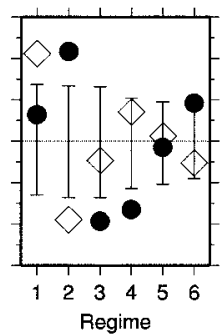

c) Gunnison River

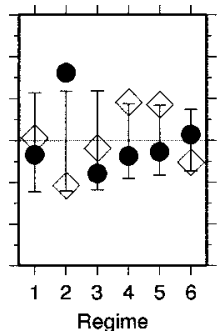

g) W. Washington

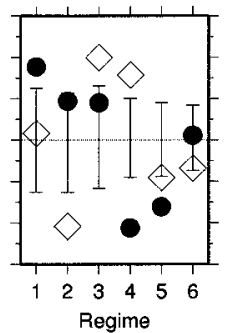

d) Rio Grande

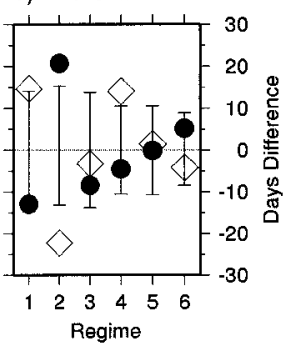

h) Yellowstone River

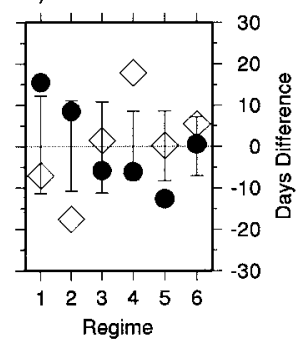

FIG. 9. Differences in regime frequency (days per winter) for locally warm-minus-cold winters (circles) and wet-minus-dry ones (diamonds). Error bars indicate the $90 \%$ confidence interval, based on random reshuffling of the 46 winters (temperatures) 1000 times.

currence of the PNA regime tend to be warm and dry; the opposite is the case for the RNA. The contrast is most statistically significant for the Central Sierra and Virgin River time series.

\section{Relationships with tropical and extratropical SST \\ a. ENSO effects on the regimes}

It is well known that the extratropical circulation over the North Pacific is affected by warm (El Niño) and cold (La Niña) events in the eastern tropical Pacific (e.g., Horel and Wallace 1981; Kumar and Hoerling 1997). Kimoto (1989) has demonstrated that the distribution of certain sectorial weather regimes (see $\mathrm{KG}$ ) is biased according to the phase of the Southern Oscillation index (SOI), with a weak but statistically significant preference toward the PNA for negative SOI values (El Niño). Similar results have been obtained from GCM experiments (Horel and Mechoso 1988; Brankovic et al. 1994).

Figures 10a and 10b illustrate the regime frequencies during El Niño and La Niña winters, respectively; these are defined here by excursions of the standardized SOI, averaged over the corresponding winter, that exceed 1.0 in absolute value: negative for El Niño (SOI $<-1.0$; panel a) and positive for La Niña (SOI > 1.0; panel b). The error bars denote the $95 \%$ significance level, based on 1000 random reshufflings; they have different lengths in the two panels because there are $11 \mathrm{El} \mathrm{Niño} \mathrm{events}$ (Fig. 10a) but only 8 La Niñas (Fig. 10b), so defined in terms of SOI for the 46 winters 1949-1995.
Regime 1 is more prevalent during El Niño winters, and less prevalent during La Niña, just above the $95 \%$ significance level. Regime 6 is less prevalent during El Niño winters at the same significance level, and tends to be more prevalent during La Niña. By contrast, the PNA and RNA regimes (regimes 2 and 4) show only weak changes in frequency, and then only during La Niña winters. Similar results are obtained if a 0.5 threshold is used for the standardized SOI, or if simulated annealing or the $K$-means regime definitions are used.

Composite SST anomalies for the winters with regime frequencies above the 80th percentile are plotted in Fig. 11, giving a sample of 10-12 winters for each regime. Again, very similar patterns were obtained using regimes derived by simulated annealing or the $K$-means method. Regime 1 is associated with SST anomalies in both the tropical and North Pacific that are the hallmark of El Niño. We have corroborated this relationship using a joint multichannel singular spectrum analysis (Kimoto et al. 1991; Plaut and Vautard 1994; Dettinger and Ghil 1998) of SST and 700-mb geopotential height data over the Pacific sector. During the El Niño phase of the joint analysis, as expressed by the SST anomalies, the height pattern closely resembles regime 1 (not shown). The present results are consistent with the TNH nature of regime 1 (Barnston and Livezey 1985; Mo 1985) and with the studies of Horel and Wallace (1981) and Deser and Blackmon (1995). These authors found North Pacific height anomalies associated with El Niño to exhibit a northwest-southeast tilt over the North Pacific, and thus to differ from the PNA pattern.

Regime 6 is associated with statistically significant 
a) $\mathrm{SOI}<-1 \sigma$

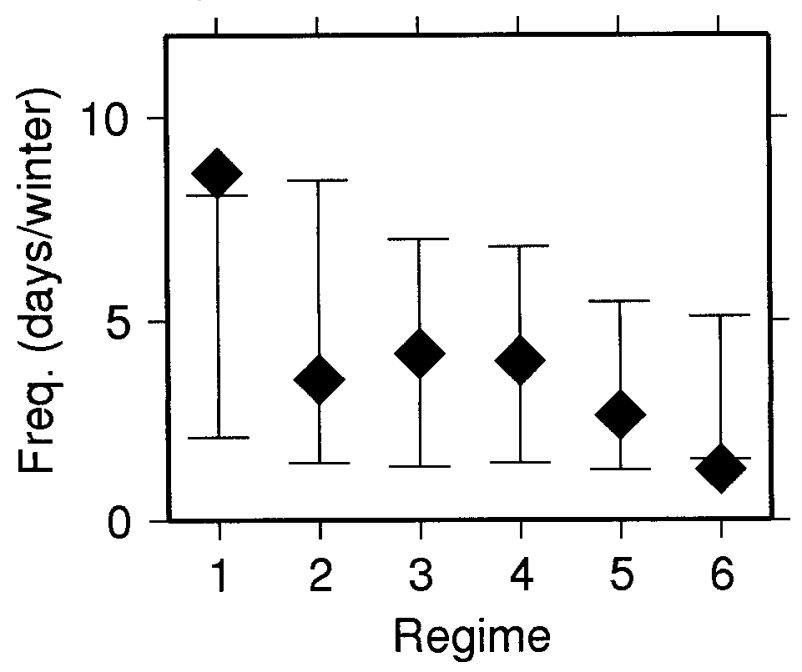

b) $\mathrm{SOI}>+1 \sigma$

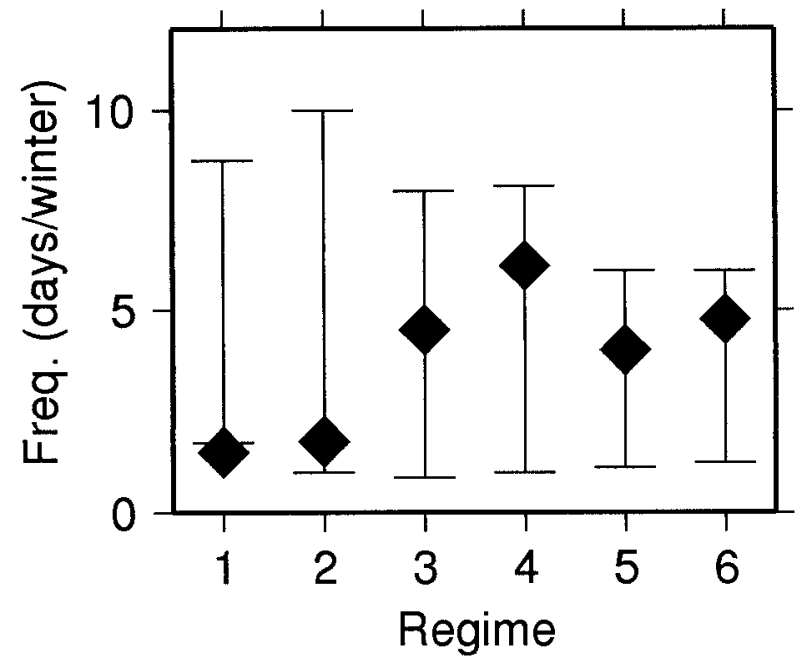

FIG. 10. Regime frequency (days/winter) for (a) El Niño, and (b) La Niña winters, defined by deviations of the SOI exceeding one standard deviation. Error bars indicate the $95 \%$ confidence interval, based on random reshuffling of the 46 winters 1000 times.

composite SST anomalies in the eastern equatorial $\mathrm{Pa}$ cific characteristic of La Niña: these are weaker than in the El Niño case, which is consistent with the smaller statistical significance of these regimes' frequency difference in Fig. 10, and with a nonlinearity in the weather regimes' response to ENSO. Again, the association of the PNA and RNA with opposite ENSO phases is much weaker than that of regimes 1 and 6 .

The PNA and RNA (regimes 2 and 4) are associated with SST anomalies over the central and eastern North Pacific of opposite signs, but only a small-to-moderate fraction of the anomalies' spatial pattern is statistically significant. These anomalies can be interpreted qualitatively in terms of the latent heat flux anomalies that accompany the most frequently occurring weather regimes (Cayan 1992).

\section{b. Interdecadal variations}

The atmosphere over the North Pacific-North American sector is known to exhibit considerable variability on decadal timescales and longer (e.g., Trenberth 1990). In particular, the Aleutian low deepened significantly during the winter seasons of the decade 1977-88 (e.g., Nitta and Yamada 1989). Figure 12 shows the interdecadal variability in weather-regime frequency, as captured by 10 -winter running means. The prevalence of the PNA (regime 2) shows a pronounced long-term variation, with a substantially increased frequency-of-occurrence during the 1970s and early 1980s. Regime 1, on the other hand, shows a decrease in frequency during the early 1970s, followed by a rise in the late 1980s.

Marked changes in the Aleutian low's intensity are a feature of both regime 2 (the PNA) and regime 1 (the $\mathrm{TNH}$ ). The changes in prevalence of these two regimes during the 1970s and 1980s suggest that the "decadal shift" in this intensity over the 1977-88 decade may in fact be a combination of two different phenomena. One of them is an El Niño-related change in the TNH pattern's (regime 1) frequency; the other is a change in the PNA pattern's frequency-of-occurrence that is phaseshifted in time with respect to the TNH. On the decadal timescale, the PNA may be affected more by midlatitude SST changes, whether due to ocean-atmosphere interaction in the North Pacific (e.g., Latif and Barnett 1994; Robertson 1996) or to internal midlatitude oceanic variability (Jiang et al. 1995; Speich et al. 1995). The decadal episode of high PNA prevalence seen in Fig. 12 is accompanied by an SST change (not shown) similar to that apparent in Fig. 11b, with pronounced negative SST anomalies over the North Pacific but weak equatorial ones.

\section{Summary and discussion}

We have investigated (i) the extent to which the daily distributions of temperature and precipitation over eight small-extent regions in the western United States (see Fig. 1) are controlled by weather regimes over the North Pacific-North American sector during winter, and (ii) how much these regimes themselves depend on the phase of ENSO. One-point correlation maps between 700-mb geopotential height fields averaged over the 3month winter (DJF) for a 46-winter period, on the one hand, and local temperature and precipitation time series in the western United States (Figs. 2 and 3), on the other, both show strong correlations, locally as well as remotely, over the North Pacific. Local correlations are positive for temperature and negative for precipitation. 
a) Regime 1 (10)

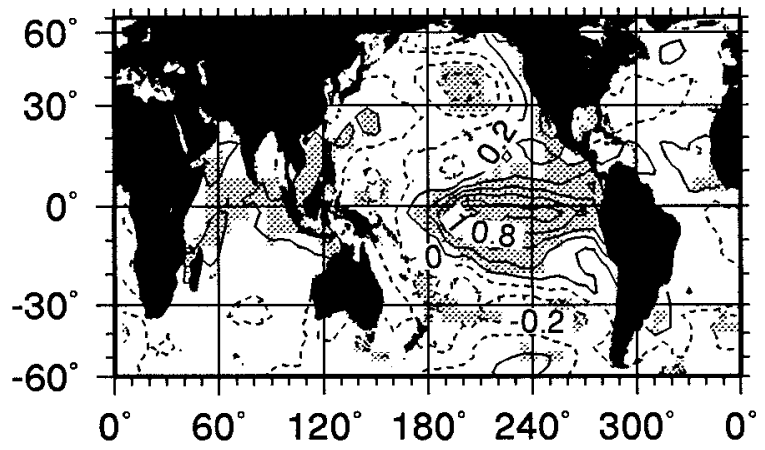

c) Regime $3(11)$

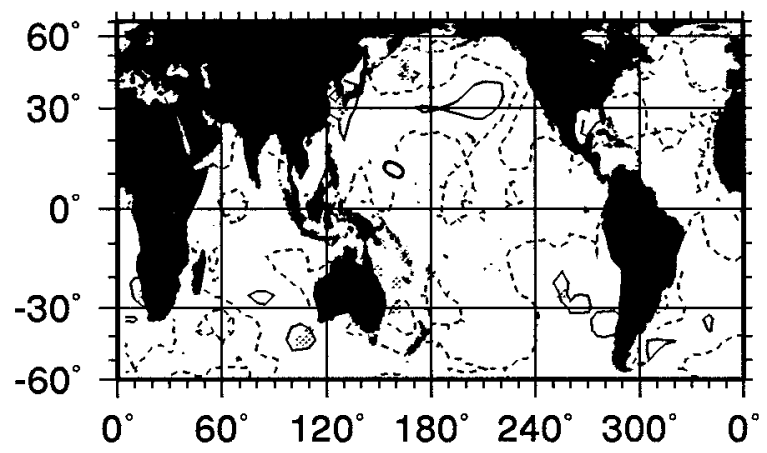

e) Regime 5 (12)

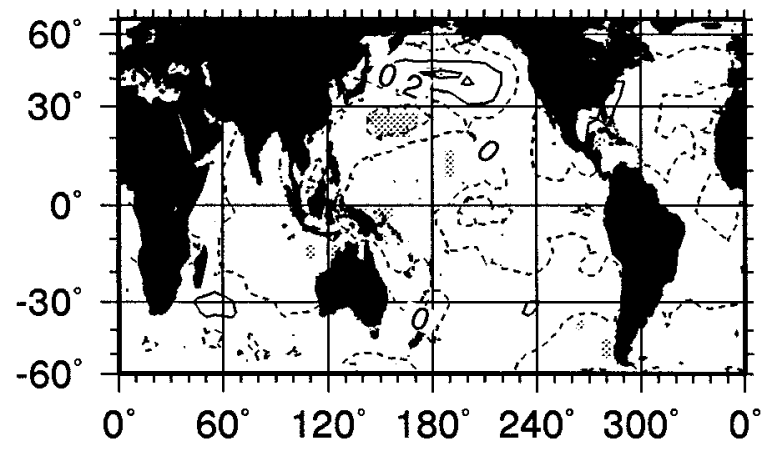

b) Regime 2 (10)

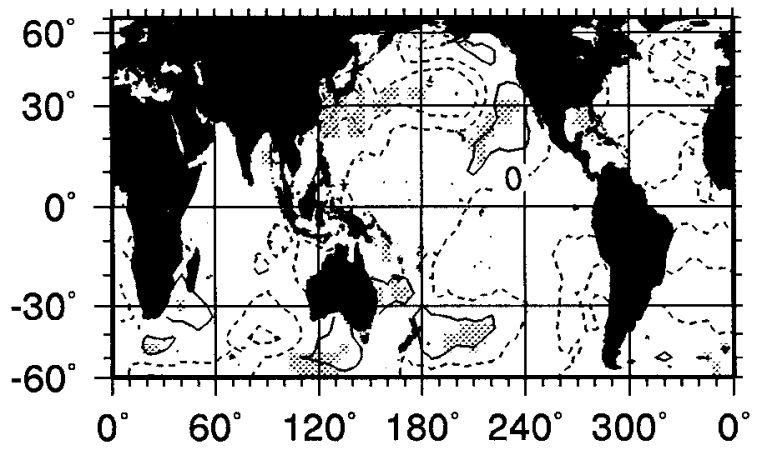

d) Regime 4 (11)

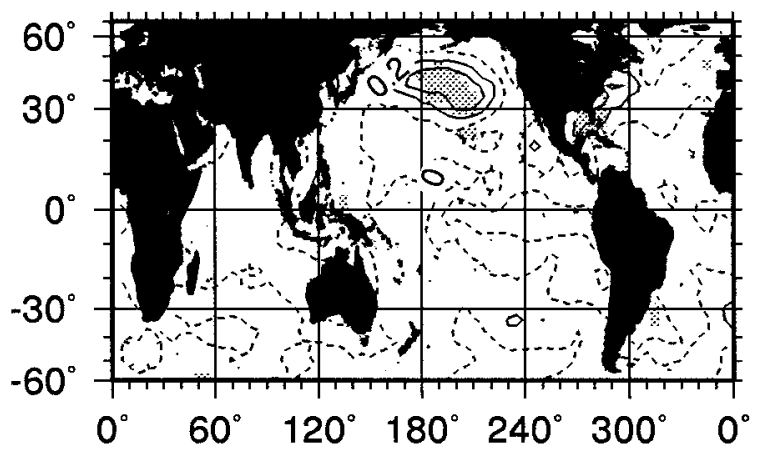

FIG. 11. Composites of SST anomalies for winters in which regime frequency exceeds the 80th percentile of the 46-winter frequency distribution. The number of winters selected for each regime is given in parentheses. Contour interval is $0.2 \mathrm{~K}$, negative and zero contours are dashed. Stippling denotes statistical significance according to a two-tailed Student's t-test at the 95\% level. (a) Regime 1: the DJF winters are 1952, 1957, 1959, 1965, 1968, 1969, 1977, 1982, 1986, and 1991, where the year in which the winter starts is given. (b) Regime 2 : 1957, 1967, 1969, 1973, 1976, 1977, 1980, 1984, 1985, and 1989. (c) Regime 3: 1951, 1958, 1964, 1966, 1971, 1974, 1978, 1987, 1988, 1989, and 1991. (d) Regime 4: 1949, 1951, 1956, 1958, 1970, 1971, 1981, 1984, 1990, and 1992. (e) Regime 5: 1951, 1956, 1961, 1962, 1971, 1973, 1977, 1980, 1981, 1983, 1990, and 1992 (f) Regime 6: 1950, 1952, 1955, 1961, 1967, 1970, 1980, 1984, 1985, and 1993. 


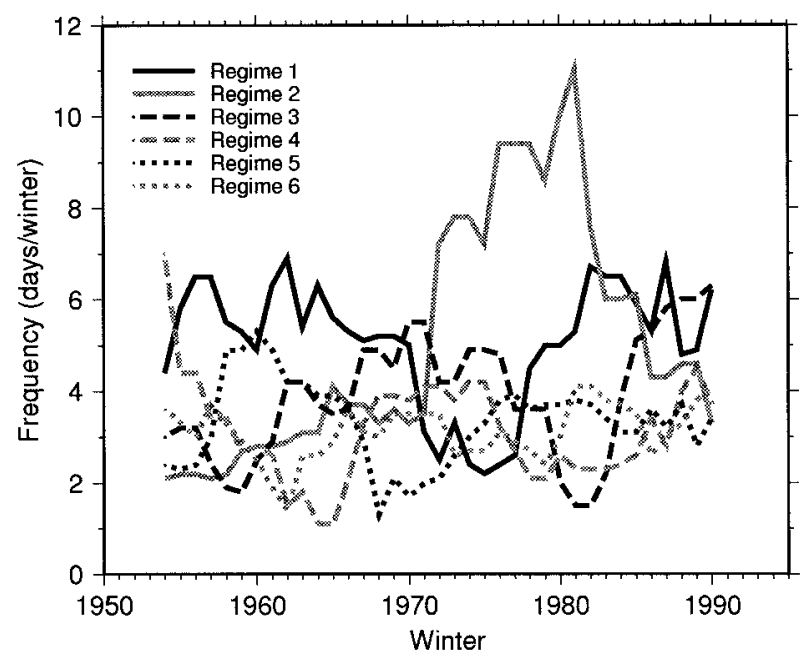

FIG. 12. Ten-year running means of frequency of occurrence within a given winter for each weather regime; see legend for regime identification.

Sizable and coherent remote correlations occur upstream in both cases; the temperature correlations show strong projections onto the PNA pattern, while the precipitation correlation patterns appear more subtle. The correlation patterns vary as one moves southward from the Yellowstone River to the Salt River, especially in the case of precipitation.

Two independent methods of defining weather regimes were applied to lowpass-filtered winter geopotential heights over the North Pacific-North American sector, the PDF bump-hunting method (KG), and the $K$-means method (MVL). The PDF method yields six regimes, for which the composite daily maps (Fig. 4) show a number of familiar synoptic features. These regimes include the well-known PNA and RNA patterns (Wallace and Gutzler 1981; Dole and Gordon 1983), as well as further patterns identified by previous authors (Table 2). Broadly speaking, the regimes fall into two categories: those with a trough over the North Pacific and a ridge downstream over western North America (regimes 1,2, and 6), and vice versa (regimes 3, 4, and 5). These two broad categories correspond to the sectorial results of Cheng and Wallace (1993) and of Smyth et al. (1999).

When carrying out the classification based on the $K$-means method, with $K=6$, the composite maps (not shown) for the six clusters are quite similar to those in Fig. 3. This is remarkable, given that the PDF method classifies only $26 \%$ of days belonging to a regime, whereas all days are classified by the $K$-means method. A number of other sensitivity tests (section 4c) allow us to conclude that the present sectorial-classification results are fairly robust.

Daily temperature and precipitation measurements in the eight small regions were partitioned into subsets according to the weather regime. Local distributions for each subset were compared with the full set of $N=46$ $\times 90=4140$ winter days, with statistical significance estimated by reshuffling the days 1000 times. Regime deviations in median temperature are generally significant at the $95 \%$ level for all regimes, except regime 1, in all eight regions (Fig. 5). Deviations in the warm and cold tails correspond with some exceptions to those in the median (Fig. 7). There are fewer significant deviations in precipitation frequency (Fig. 8), and deviations in the tail of the local precipitation distributions are generally not significant. The main dependencies of local temperature (Figs. 5 and 7) and precipitation (Fig. 8 ) on weather regime are as follows.

- The PNA and RNA (regimes 2 and 4, respectively) are associated with the largest contrasts in local temperature and precipitation; the PNA tends to yield warm and dry weather in almost all eight regions, while the RNA is cold and wet. The contrast in temperature can be interpreted in terms of an anomalous ridge (PNA) or trough (RNA) over the western United States, with advection of warm or cold air, respectively, from the North Pacific onto land (Figs. 6b and $6 \mathrm{~d})$. The contrast in the probability of wet days can be associated with shifts in the storm track; for the PNA it is deflected northeastward into Alaska (Fig. 6b), while over the western United States the RNA is associated with cold storms of subarctic origin (Fig. 6d).

- Regimes with anomalous ridging over the North Pacific and a trough downstream over the Rocky Mountains (regimes 3, 4, and 5) are on average colder than the zonal regimes $(1,2$, and 6$)$ at most localities. The ridge regimes over the eastern Pacific tend to be wetter in the south.

- Region-to-region variations are most marked in the tails of the temperature distribution: regime $5(\Omega$ block) is associated with a much larger number of extremely cold days in western Washington and the Yellowstone River regions than anywhere else, while regime 4 (the RNA) is much more often associated with extreme cold in the Sierra Nevada. Subtle changes in the position of the trough axis over North America are responsible for these differences (Figs. 6d vs 6e).

Interannual anomalies in temperature and precipitation frequency for the various locations are generally found to be associated with interannual changes in weather regime frequency (Fig. 9). In cases where the large-scale regimes can be identified unequivocally with a tendency for wetness or dryness at a given location, wet years do in most cases differ significantly from dry years in terms of the frequency of the corresponding regimes. The same is true for temperature.

Due to the small extent of the dataset in hand, these conclusions on interannual variability of local phenomena hold only when using the $K$-means regime classification method; the PDF regimes contain too few days 
to allow interannual anomalies at most locations to be characterized with high statistical significance. Except for Fig. 9, we have focused on the PDF regimes because they are dynamically more transparent: highly localized regions of state space can be equated with recurrent circulation patterns and thus with relative stability of the circulation. The $K$-means method, on the other hand, partitions the entire dataset and makes therewith the dynamical interpretation of the resulting regimes less compelling.

The trade-off between the dynamical and statistical significance of the regimes obtained with either method is fairly straightforward. Each 90-day winter has about three to four persistent occurrences of one of the six PDF regimes. This provides fairly stable statistics for the regime-to-regime variability of the local temperature and precipitation, while it takes the four-times greater membership of the $K$-means regimes to provide equally stable statistics for the year-to-year variability within the 46-yr dataset.

Since interannual anomalies in local temperature and precipitation can be partially characterized in terms of changes in weather-regime frequency, we have investigated how the latter are related to ENSO and to North Pacific SST anomalies. The former dependence was explored in terms of each regime's frequency-of-occurrence during low- versus high-SOI winters (Fig. 10), and both dependencies were considered by plotting SST anomalies during winters in which a particular regime occurs most frequently (Fig. 11). In terms of the six PDF regimes identified (Fig. 4), ENSO is characterized by the anomalously high frequency of a TNH pattern (regime 1) during El Niño winters (Fig. 10a), and a relative absence of this regime during La Niña (Fig. 10b). To a smaller extent, regime 6 is less frequent during El Niño winters and more prevalent during La Niña. On the other hand, the PNA and RNA (regimes 2 and 4) show only a weak association with ENSO (Figs. 10a and 10b; their association with SST anomalies in the central and eastern North Pacific, on the other hand, is quite significant (Figs. 11b and 11d). Our results suggest that the teleconnections associated with ENSO over the North Pacific-North American sector during winter are largely due to the anomalous frequency of the TNH pattern, rather than to a linear response characterized by the PNA and RNA.

On interdecadal timescales by contrast, the largest changes in weather-regime frequency are associated with the PNA (Fig. 12). Thus different weather regimes appear to dominate fluctuations over the North Pacific on interannual timescales versus interdecadal ones. This finding, which is suggestive of different atmospheric mechanisms, is consistent with the analyses of Deser and Blackmon (1995). The anomalously deep Aleutian low of the decade 1977-88 appears to arise from a combination of both regimes 1 and 2; their frequencies of occurrence have different decadal evolutions, so that the "decadal shift" of Venrick et at. (1987) and Nitta and
Yamada (1989) may be the result of more than one dynamical phenomenon. At least two separate mechanisms have been proposed for North Pacific SST changes on this timescale: the basin's internal variability (Jiang et al. 1995; Speich et al. 1995), and its coupled variability with the overlying atmosphere (Latif and Barnett 1994; Robertson 1996).

In terms of temperature, the regional effects of regime 1-the one associated with El Niño-are always weaker than those of the PNA, which is more closely associated with North Pacific SST anomalies. Both tend to yield relatively warm weather across the western United States, but the effects of the TNH pattern are only significantly warmer in the north, with fewer cold extremes across the entire western United States. In terms of precipitation frequency, regimes 1 and 2 are generally characterized by anomalies of opposite sign. Regime 1 is significantly wetter in the Sierra Nevada and the Southwest, and significantly drier at the Yellowstone River in the north. Regime 2 is significantly drier in almost all eight regions. Thus, the distinction between the TNH and PNA (regimes 1 and 2) is also emphasized in terms of regional impacts. These two weather regimes coalesce in analyses that support only fewer clusters over the North Pacific, for example, Smyth et al.'s (1999) or our analysis based on the covariance-rather than the correlation-matrix. This indicates that potentially important but subtle distinctions between regimes may have to await the advent of longer observed datasets or the use of well-validated and longer atmospheric simulations with general circulation models (Ghil 1995).

Regime 6 tends to be more strongly associated with La Niña than the RNA (regime 4), both in terms of SOI values and SST anomalies, although the association is somewhat weaker than for regime 1 with El Niño (Figs. 10 and 11). Regime 6 tends to result in significantly warmer weather throughout the west, and is drier in the Southwest and wetter in the northwest. It thus contrasts with regime 1, whose frequency of occurrence is enhanced by El Niño and which is wetter in the Sierra Nevada and the Southwest but drier at the Yellowstone River. Regimes 1 and 6 may thus contribute to the northsouth contrast in precipitation over western North America during ENSO events found by previous authors (e.g., Cayan and Webb 1992), while our results indicate that, on the whole, La Niña has a less well-defined influence on the atmosphere over the North Pacific and the western United States.

The relationships between weather regimes and regional weather, on the one hand, and these regimes and ENSO, on the other, were derived for six specific regimes. However, the qualitative nature and statistical significance of these relationships is not limited too severely by the methodology used in the classification. Our results showed little sensitivity to including as little as one-quarter of all maps, when using KG's PDF bumphunting method, as many as all maps, when using MVL's $K$-means method, or about half the maps, when using 
Hannachi and Legras's (1995) simulated annealing to identify the regimes. Likewise, the results showed little sensitivity to the size and way of defining the EOF subspace in which the classification was carried out. We can hope, therefore, that the present results are fairly robust and insensitive to the exact choice of blocked and zonal regimes over the North Pacific-North American sector.

Acknowledgments. It is a pleasure to thank D. Cayan, M. Dettinger, and M. Kimoto for fruitful discussions. We are especially grateful to D. Cayan, L. Riddle, and Scripps Institution of Oceanography's Climate Research Division for providing the regional data, M. Dettinger for supplying the geopotential height data, and to $\mathrm{S}$. Koo for coding the $K$-means clustering algorithm. Constructive comments from two anonymous referees helped clarify the presentation and resulted in the inclusion of Figs. 6 and 12. This work was supported by the University of California's Campus-Laboratory Collaboration program and by NASA Grant NAG 5-713.

\section{REFERENCES}

Aguado, E., D. Cayan, L. Riddle, and M. Roos, 1992: Climatic fluctuations and the timing of West Coast streamflow. J. Climate, 5, 1468-1483.

Anderson, T. W., 1958: An Introduction to Multivariate Statistical Analysis. John Wiley and Sons, $374 \mathrm{pp}$.

Bardossy, A., and E. J. Plate, 1992: Space-time model for daily rainfall using atmospheric circulation patterns. Water Resour. Res., 28, 1247-1259.

Barnston, A. G., and R. E. Livezey, 1985: A high resolution rotated EOF analysis of monthly and seasonally averaged $700 \mathrm{mb}$ heights. Proc. Ninth Conf. on Probability and Statistics in Atmospheric Sciences, Virginia Beach, VA, Amer. Meteor. Soc., 290-297.

— , and — 1987: Classification, seasonality and persistence of low-frequency atmospheric circulation patterns. Mon. Wea. Rev., 115, 1083-1126.

Bauer, F., 1951: Extended-range weather forecasting. Compendium of Meteorology, T. F. Malone, Ed., Amer. Meteor. Soc., 814833.

Benzi, R., P. Malguzzi, A. Speranza, and A. Sutera, 1986: The statistical properties of general atmospheric circulation: Observational evidence and a minimal theory of bimodality. Quart. J. Roy. Meteor. Soc., 112, 661-674.

Blackmon, M. L., and N.-C. Lau, 1980: Regional characteristics of the Northern Hemisphere wintertime circulation: A comparison of the simulation of a GFDL general circulation model with observations. J. Atmos. Sci., 37, 497-514.

- R. A. Madden, J. M. Wallace, and D. S. Gutzler, 1979: Geographical variations in the vertical structure of geopotential height fluctuations. J. Atmos. Sci., 36, 2450-2466.

Brankovic, C., T. N. Palmer, and L. Ferranti, 1994: Predictability of seasonal atmospheric variations. J. Climate, 7, 217-237.

Cayan, D. R., 1992: Latent and sensible heat flux anomalies over the northern oceans: Driving the sea surface temperature. J. Phys. Oceanogr., 22, 859-881.

— streamflow in the western United States. El Niño: Historical and Paleoclimatic Aspects of the Southern Oscillation, H. F. Diaz and V. Markgraf, Eds., Cambridge University Press, 29-69.

Charney, J. G., and J. G. DeVore, 1979: Multiple flow equilibria in the atmosphere and blocking. J. Atmos. Sci., 36, 1205-1216.
Cheng, X., and J. M. Wallace, 1993: Cluster analysis of the Northern Hemisphere wintertime 500-hPa height field: Spatial patterns. J. Atmos. Sci., 50, 2674-2696.

Corti, S., and T. N. Palmer, 1997: Sensitivity analysis of atmospheric low-frequency variability. Quart. J. Roy. Meteor. Soc., 123, $2425-2448$

Deser, C., and M. L. Blackmon, 1995: On the relationship between tropical and North Pacific sea surface temperature variations. $J$. Climate, 8, 1677-1680.

Dettinger, M. D., and D. R. Cayan, 1992: Climate-change scenarios for the Sierra Nevada, California, based on winter atmosphericcirculation patterns. Proc. American Water Resources Symp. on Managing Water Resources During Global Change, Reno, NV, American Water Resources Assoc., 681-690.

_ , and M. Ghil, 1998: Seasonal and interannual variations of atmospheric $\mathrm{CO}_{2}$ and climate. Tellus, 50B, 1-24.

,-- , and C. L. Keppenne, 1995: Interannual and interdecadal variability in United States surface-air temperatures, 1910-87. Climate Change, 31, 35-66.

Dole, R. M., 1986: Persistent anomalies of the extratropical Northern Hemisphere wintertime circulation: Structure. Mon. Wea. Rev., 114, 178-207.

— , and N. M. Gordon, 1983: Persistent anomalies of the extratropical Northern Hemisphere winter time circulation: Geographical distribution and regional persistence characteristics. Mon. Wea. Rev., 111, 1567-1586.

Fukunaga, K., and L. D. Hostetler, 1975: The estimation of the gradient of a density function. IEEE Trans. Inf. Theory, 21, 32-40.

Gershunov, A., and T. Barnett, 1998: ENSO influence on intraseasonal extreme rainfall and temperature frequencies in the contiguous United States: Observations and model results. J. Climate, 11, 1575-1586.

Ghil, M., 1995: Atmospheric modeling. Natural Climate Variability on Decade-to-Century Time-Scales, D. G. Martinson et al., Eds., National Academy Press, 164-168.

— Atmospheric Dynamics, Dynamo Theory and Climate Dynamics. Springer-Verlag, $485 \mathrm{pp}$.

Hannachi, A., and B. Legras, 1995: Simulated annealing and weather regimes classification. Tellus, 47A, 955-973.

Horel, J. D., and J. M. Wallace, 1981: Planetary-scale atmospheric phenomena associated with the Southern Oscillation. Mon. Wea. Rev., 109, 813-829.

— sonal variability of the wintertime planetary circulation. $\mathrm{J}$. Climate, 1, 582-599.

Hughes, J. P., D. P. Lettenmaier, and P. Guttorp, 1993: A stochastic approach for assessing the effect of changes in regional circulation patterns on local precipitation. Water Resour. Res., 29, 3303-3315.

IMSL Inc., 1991: IMSL Stat/Library. 1578 pp.

Jiang, S., F.-F. Jin, and M. Ghil, 1995: Multiple equilibria, periodic, and aperiodic solutions in a wind-driven, double-gyre, shallowwater model. J. Phys. Oceanogr., 25, 764-786.

Kimoto, M., 1989: Multiple flow regimes in the Northern Hemisphere winter. Ph.D. thesis, University of California, Los Angeles, 210 pp. [Available from UCLA, Box 951575, Los Angeles, CA 90095-1575.]

_ , and M. Ghil, 1993a: Multiple flow regimes in the Northern Hemisphere winter. Part I: Methodology and hemispheric regimes. J. Atmos. Sci., 50, 2625-2643.

$\longrightarrow$, and $\_$1993b: Multiple flow regimes in the Northern Hemisphere winter. Part II: Sectorial regimes and preferred transitions. J. Atmos. Sci., 50, 2645-2673.

- _ - , and K.-C. Mo, 1991: Spatial structure of the extratropical 40-day oscillation. Proc. Eighth Atmos. and Oceanic Waves and Stability Conf., Boston, MA, Amer. Meteor. Soc., J17-J20.

Kumar, A., and M. P. Hoerling, 1997: Interpretation and implications of observed inter-El Niño variability. J. Climate, 10, 83-91.

Latif, M., and T. P. Barnett, 1994: Causes of decadal climate vari- 
ability over the North Pacific/North American sector. Science, 266, 634-637.

Legras, B., and M. Ghil, 1985: Persistent anomalies, blocking and variations in atmospheric predictability. J. Atmos. Sci., 42, 433471.

MacQueen, J., 1967: Some methods for classification and analysis of multivariate observations. Proc. Fifth Berkeley Symp. on Mathematical Statistics and Probability, Berkeley, CA, University of California Press, 281-297.

Michelangeli, P. A., R. Vautard, and B. Legras, 1995: Weather regimes: Recurrence and quasi-stationarity. J. Atmos. Sci., 52, 1237-1256.

Miyakoda, K., C. T. Gordon, R. Caverly, W. F. Stern, J. Sirutis, and W. Bourke, 1983: Simulation of a blocking event in January 1977. Mon. Wea. Rev., 111, 846-869.

Mo, K. C., 1985: Interhemispheric correlation statistics during Northern Hemisphere winter. Proc. Ninth Conf. on Probability and Statistics in Atmospheric Sciences, Virginia Beach, VA, Amer. Meteor. Soc., 283-289.

— , and M. Ghil, 1988: Cluster analysis of multiple planetary flow regimes. J. Geophys. Res., 93D, $10927-10952$.

— J. R. Zimmerman, E. Kalnay, and M. Kanamitsu, 1991: A GCM study of the 1988 United States drought. Mon. Wea. Rev., 119, $1512-1532$.

Molteni, F., S. Tibaldi, and T. N. Palmer, 1990: Regimes in the wintertime extratropical circulation. Part I: Observational evidence. Quart. J. Roy. Meteor. Soc., 116, 31-67.

—, L. Ferranti, T. N. Palmer, and P. Viterbo, 1993: A dynamical interpretation of the global response to equatorial Pacific SST anomalies. J. Climate, 6, 777-795.

Namias, J., and D. Cayan, 1984: El Niño implications for forecasting. Oceanus, 27, 40-45.

Nitta, T., and S. Yamada, 1989: Recent warming of tropical seasurface temperature and its relationship to the Northern Hemisphere circulation. J. Meteor. Soc. Japan, 67, 375-383.

Plaut, G., and R. Vautard, 1994: Spells of low-frequency oscillations and weather regimes in the Northern Hemisphere. J. Atmos. Sci., $\mathbf{5 1}, 210-236$.

Press, W. H., B. P. Flannery, S. A. Teukolsky, and W. T. Vetterling, 1992: Numerical Recipes in FORTRAN. 2d ed. Cambridge University Press, $702 \mathrm{pp}$.

Rheinhold, B. B., and R. T. Pierrehumbert, 1982: Dynamics of weath- er regimes: Quasi-stationary waves and blocking. Mon. Wea. Rev., 110, 1105-1145.

Robertson, A. W., 1996: Interdecadal variability in a multicentury climate integration. Climate Dyn., 12, 227-241.

— , and W. Metz, 1990: Transient-eddy, feedbacks derived from linear theory and observations. J. Atmos. Sci., 47, 2743-2764.

Ropelewski, C. F., and M. S. Halpert, 1987: Global and regional scale precipitation associated with El Niño/Southern Oscillation. Mon. Wea. Rev., 115, 1606-1626.

_ , and - 1996: Quantifying Southern Oscillation-precipitation relationships. J. Climate, 9, 1043-1059.

Smyth, P., M. Ghil, and K. Ide, 1999: Multiple regimes in Northern Hemisphere height fields via mixture model clustering. J. Atmos. Sci., in press.

Speich, S., H. Dijkstra, and M. Ghil, 1995: Successive bifurcations in a shallow-water model, applied to the wind-driven ocean circulation. Nonlin. Proc. Geophys., 2, 241-268.

Tibaldi, S., and F. Molteni, 1990: On the operational predictability of blocking. Tellus, 42A, 343-365.

Trenberth, K. E., 1990: Recent observed interdecadal climate changes in the Northern Hemisphere. Bull. Amer. Meteor. Soc., 71, 988993.

Vautard, R., 1990: Multiple weather regimes over the North Atlantic. Analysis of precursors and successors. Mon. Wea. Rev., 118, 2056-2081.

- , and B. Legras, 1988: On the source of low frequency variability. Part II: Nonlinear equilibration of weather regimes. J. Atmos. Sci., 45, 2845-2867.

—, K. C. Mo, and M. Ghil, 1990: Statistical significance test for transition matrices of atmospheric Markov chains. J. Atmos. Sci., 47, 1926-1931.

Venrick, E. L., J. A. McGowan, D. R. Cayan, and T. L. Hayward, 1987: Climate and chlorophyll: Long-term trends in the central North Pacific Ocean. Science, 238, 70-72.

Wallace, J. M., and D. S. Gutzler, 1981: Teleconnections in the potential height field during the Northern Hemisphere winter. Mon. Wea. Rev., 109, 784-812.

Wilson, L. L., D. P. Lettenmaier, and E. Skyllingstad, 1992: A multiple stochastic daily precipitation model conditional on large-scale atmospheric circulation patterns. J. Geophys. Res., 97, 27912809.

Zorita, E., J. P. Hughes, D. P. Lettenmaier, and H. von Storch, 1995: Stochastic characterization of regional circulation patterns for climate model diagnosis and estimation of local precipitation. $J$. Climate, 8, 1023-1042. 